\title{
ANTOLOGUEMOS: TENDENCIAS, INERCIAS Y DERIVAS DE LAS ÚLTIMAS ANTOLOGÍAS POÉTICAS EN LA ESPAÑA CONTEMPORÁNEA
}

Tendencies, Inerties and Drifts in the Last Poetic Anthologies in the Contemporary Spain

\author{
RAÚl MOLINA GIL \\ UNIVERSIDAD DE VALENCIA raul.molina@uv.es
}

RECIBIDO: 15 DE MAYO DE 2018

ACEPTADO: 29 DE JUNIO DE 2018

RESUMEN: La historia de la poesía en las últimas décadas, los procesos de canonización y la lucha por la hegemonía del campo poético han estado en gran medida determinados en España por las propuestas antológicas. Han sido estos compendios los que han señalado las líneas de fuerza y los que han aupado a poéticas y poetas hacia los espacios centrales del panorama poético. No es un juego inocente, pues residen en ello numerosos factores ideológicos y, también, mercantiles, que no solo afectan al espacio de la escritura poética, sino a la estructuración de la cultura y de lo socio-político. Desde la crítica, mirar estos espacios se antoja necesario. Más si cabe en un proceso en marcha, como el que implica a los autores nacidos a partir de 1980 y que comenzaron a publicar en el nuevo milenio. Sobre las antologías que han recogido sus composiciones versa este artículo, en un intento de cartografiar un desierto no demasiadas veces transitado.

PALABRAS CLAVE: Poesía española actual, Antologías poéticas, Campo poético, Siglo XXI.

ABSTRACT: In Spain, the history of the poetry in the last decades, the canonization processes and hegemony fights in the poetry field have been largely caused by the anthologies. These books influenced the position of the poets and the poetics into the structure of the poetry field. It is not a naïve action, because it involves a lot of ideology and commercial elements, which can affect not the poetry writing and the cultural and sociopolitical organization. So, it is crucial to study this spaces from a critical point of view, even further in this kind of process, which involves the writers who were born after 1980. In this article, we will analyze the anthologies that contain the poetry work of these poets.

KEYWORDs: Present Spanish poetry, Poetry anthologies, Poetry Field, Twenty-First century

Molina Gil, Raúl.

“Antologuemos: tendencias, inercias y derivas de las últimas antologías poéticas en la España contemporánea”.

Kamchatka. Revista de análisis cultural 11 (Julio 2018): 57-109

DOI: 10.7203/KAM.11.12481 ISSN: 2340-1869

Monográfico LECTURAS DEL DESIERTO: NUEVAS PROPUESTAS POÉTICAS EN ESPAÑA 


\section{SOBRE LA PRÁCTICA ANTOLÓGICA: BREVES APUNTES PRELIMINARES}

Las antologías sí que se leen. Creo que a partir de ahora solo escribiré antologías

Manuel Vázquez Montalbán (Castellet, 2011: 57)

Dice Jordi Doce que el concepto de antología, tal como se ha ido conformando en los últimos años, se inserta en una concepción de la lectura equivalente a la comida rápida y preparada (Doce, 2005: 297), una suerte de rapping, como irónicamente lo ha definido Miguel Casado (Doce, 2005: 297), relacionado en la inmensa mayoría de las ocasiones con la legitimación de una determinada corriente o grupo poético. Ambos hablan desde la clara constatación de que la práctica antológica se ha visto modificada por la profusión de publicaciones a lo largo de las últimas décadas, un aumento que podemos explicar a partir de las estrategias del mercado capitalista fundamentadas en el auge de lo publicitario (Talens, 1989) y en la voluntad de acumulación de "capital simbólico" y "económico" (utilizando la terminología de Bourdieu, 1995); en la aceleración y el presentismo que articulan la vida diaria de las sociedades actuales, tal y como los comprendían Virilio (1999) y Hartog (2007) respectivamente; y en la necesidad mercantilista del etiquetado, que "tiende a sustituir a la lectura, la inercia al movimiento, la fuerza centrípeta al descentramiento" (Méndez Rubio, 2004a: 130), y que tanta relevancia ha tenido en el campo poético español de las últimas décadas como herramienta identificadora y legitimadora de las diferentes y sucesivas generaciones poéticas, que ya no se constituyen cada quince años, como indicara Ortega y Gasset, sino cada quince meses (Doce, 2005: 295)1. Al cabo, son ejemplos todos ellos de que vivimos en una cultura de lo fragmentario en la cual quien no aparece en las antologías corre el peligro de no existir (González Moreno, 2016: 17).

Mucho ha cambiado este espacio desde finales del siglo XIX, cuando, siguiendo a Menéndez Pelayo, la antología era considerada (desde un posicionamiento un tanto idealista) como un archivo literario que testimoniaba las transformaciones del arte poético (Menéndez Pelayo, 2014: 392), hasta nuestros días, en los que pueden (e incluso deben) ser concebidas (y así las comprenderemos aquí) como unos instrumentos del poder destinados a crear unas jerarquías y unos escalafones determinados, precedidos por una construcción de una red de favores recibidos y devueltos que envuelven como melaza el trabajo de las revistas, editoriales e instituciones culturales (Doce, 2005: 297). Estas sustanciales modificaciones en la comprensión del hecho antológico no solo debemos rastrearlas en las sucesivas publicaciones (principalmente de compendios programáticos, siguiendo a Ruiz Casanova [2007]), pues no podemos obviar el papel de otras instancias legitimadoras que les han otorgado esta relevancia desde diferentes espacios del campo poético: la crítica académica, la industria editorial, los suplementos culturales, los eventos y festivales orquestados en diversos lugares de la geografía española, las redes sociales, etc. Estos desarrollos generaron una nueva poética y una nueva política de las antologías, esto es,

\footnotetext{
${ }^{1}$ El problema no radica tanto en el etiquetado como elemento clasificador de la historia literaria, es decir, en su "carácter didáctico e informativo de tales clasificaciones, que sirven de guías para desplazarnos por la confusa maraña de títulos y nombres propios que, como el bosque de espinos que oculta el castillo de la Bella Durmiente, se extiende por las estribaciones y laderas del Parnaso particular de cada época” (Doce, 2005: 298), sino que, más bien, surge "cuando tales clasificaciones dejan de tener carácter didáctico y se convierten, bien en instrumentos normativos, bien en etiquetas globales que sustituyen al ejercicio de una lectura profunda" (Doce, 2005: 298).
} 
una nueva ideología en lo que respecta a la compilación y a la recepción de las mismas, de la que somos herederos hoy en día: sin los compendios de Gerardo Diego en 1932 y 1934 no habría sido posible el Castellet de 1962 y 1970; sin este, no podemos entender a Luis Antonio de Villena o a José Luis García Martín a partir de los años ochenta; y, sin todos ellos, no existirían Luna Miguel y su Tenian veinte años y estaban locos, ya en el nuevo milenio ni, por supuesto, otras compilaciones más recientes, como las de Floriano y Rivero Machina, Díaz, Morante o Kokoro, que trataremos en páginas posteriores. La idea, por lo tanto, es analizar las derivas y devaneos que han construido el campo poético hasta nuestros días, bucear en la(s) ideología(s) que hay tras ellas para, finalmente, comprender a partir de estas inercias el rol actualmente indispensable de las antologías, en tanto objetos culturales que permiten, siguiendo de nuevo la terminología de Bourdieu en Las reglas del arte, participar en el campo poético a partir de la puesta en práctica de unas relaciones de fuerza que deriven en la lucha por las formas específicas de dominio, legitimación y hegemonía, en relaciones de alianza y conflicto y, finalmente, en la pugna por el capital (principalmente simbólico pero, también, por qué no, económico) (Bourdieu, 1995). Por todo ello creo, es más importante que nunca detenerse a reflexionar críticamente sobre este aspecto para poder comprender en qué situación nos encontramos e intentar averiguar hacia dónde nos dirigimos. Al fin y al cabo, como ya dijera Adorno en Minima Moralia: "Nada hay ya que sea inofensivo" (2004: 29).

Así pues, tras esta primera toma de contacto, en el presente artículo presentamos, en primer lugar, un recorrido histórico y crítico que nos permite comprender la relevancia de las antologías en el campo poético contemporáneo. A continuación, queremos realizar un pequeño repaso de las más relevantes antologías, protagonistas de estas derivas, desde un punto de inflexión que creemos fundamental: la publicación en 1970 de Nueve novísimos poetas españoles. Este recorrido continúa en el apartado tres, dedicado a los repertorios antológicos que participaron en la lucha por la hegemonía del campo desde espacios no centrales. Ya en las secciones del artículo afines a este monográfico, nos centramos en la participación de los nacidos en los ochenta en los diversos repertorios antológicos publicados en los primeros años del siglo XXI, para llegar, así, al análisis de otro de los puntos clave de este recorrido: Tenían veinte años y estaban locos, antología coordinada por Luna Miguel en 2011. De aquí, pasamos al análisis de los últimos compendios: aquellos, primero, que han incluido voces de los ochenta y noventa junto a otras más asentadas; segundo, aquellos que se han centrado sincrónicamente en la más reciente poesía escrita por los más jóvenes autores 2 .

\footnotetext{
2 Es evidente que este repaso exigiría, en el caso de que queramos ser exhaustivos, una extensión que en este artículo no podemos asumir. Así pues, sobre todo en el apartado 2, hemos realizado calas en las más relevantes antologías del panorama, es decir, aquellas que han conformado el relato de la historia de la poesía contemporánea y que nos permiten realizar una genealogía del discurso antológico, para comprender las ideas que atraviesan a este respecto el campo poético actual, que es, finalmente, el foco principal de reflexión de este artículo.
} 


\title{
1. UN BREVE RECORRIDO HISTÓRICO-CRÍTICO: PRESENCIA, AUGE E IMPORTANCIA DE LAS ANTOLOGÍAS EN EL CAMPO POÉTICO
}

\author{
La historia de la poesía española de las últimas \\ décadas ha sido escrita fundamentalmente desde \\ las antologías. \\ José Luis Falcó (2007: 26)
}

He querido abrir este apartado del artículo con una repetidísima cita del profesor, poeta, investigador y antólogo, José Luis Falcó, que sintetiza el papel de indiscutible relevancia de las antologías en la conformación del campo poético, esto es, en los "procesos de canonización" de autores y tendencias (Even-Zohar, 1990) 32, en los modelos de interpretación de las prácticas de escritura y, entre otros factores, en la lectura seleccionada, y por lo tanto siempre parcial, de la historia literaria española. Lo he hecho porque la considero una suerte de grieta o, mejor un umbral, un palimpsesto que (re)vela demasiado: por una parte, una actitud frente al hecho poético, que parece definirse a partir de un objetivo final en apariencia dislocado, un objetivo que no se fundamenta tanto en la publicación de poemarios con los que proponer prácticas de escritura, tomar partido y participar en las tensiones del campo poético, sino en conseguir que un puñado de esos poemas formen parte de las antologías que marcarán el devenir de los procesos de canonización ${ }^{4}$. Es evidente que afirmaciones de tal calado deben ser matizadas, y lo haremos a lo largo de este artículo. Sin embargo, lo que no podemos negar es que también esa cita entronca con una línea de pensamiento sobre el hecho antológico que podemos comenzar a rastrear en algunas de las primeras observaciones ya a finales del siglo XIX. En esos años, Menéndez Pelayo, en su Antología de poetas líricos castellanos de 1890, justificaba el valor de estas compilaciones a partir de argumentos históricos (clásicos, quizás), un tanto universalistas y fundamentadas en el poco crítico concepto del "gusto reinante":

Las antologías poéticas son casi tan antiguas como la misma poesía lírica escrita. Nada tan expuesto a perecer como estas composiciones fugaces si a tiempo no se las recoge y ata formando ramillete. Cada época, cada país, cada escuela ha conocido estos libros de selección conforme al gusto reinante. Son los archivos literarios por excelencia y el testimonio fehaciente de todas las transformaciones del arte (Menéndez Pelayo, 2014: 392).

\footnotetext{
3 Utilizaré a lo largo del artículo los términos canonizado y canonización, propuestos por Even-Zohar (1990) en el marco de la teoría de los polisistemas como sustitutos de canon y canónico, ya que permiten subrayar "que la canonicidad no es una característica inherente de los textos en ningún nivel, sino una categoría que se adquiere a lo largo de un proceso y como resultado de una actividad" (Monserrat Iglesias, 1994: 332). Para el teórico israelí, el polisistema "is a a multiple system, a system of various systems which intersect with each other and partly overlap, using concurrently different options, yet functioning as one structured whole, whose members are interdependent" (1990: 11) que se fundamenta en la tensión entre diferentes estratos: centro y periferia. Los elementos periféricos, tanto obras (canonicidad estática) como normas literarias (canonicidad dinámica), luchan por acceder al centro, donde se ubican los que ya han pasado por un proceso de canonización que los ha establecido como elementos canonizados.

4 Ya Ángel Luis Prieto de Paula decía en referencia a la generación novísima: "Aunque en los estrechos círculos poéticos fueran los libros de algunos jóvenes (y los reconocimientos que obtuvieron, como el Premio Nacional de Poesía de Arde el mar) los que avisaron del cambio de rumbo, en un ámbito cultural menos específico cumplieron esa tarea las antologías. Gracias a ellas, lo que aparecía como un conjunto de aportaciones independientes, debidas sobre todo al talento individual, pasó a considerarse como realidad compacta y generacional" (Prieto de Paula, 1996:77).
} 
Una visión similar proponía Guillermo de la Torre en el artículo "El pleito de las antologías", recogido en la compilación La aventura y el orden (1943), al considerarlas como libros de inventario, como balance de una época, tendencia o estilo y como herramientas que permiten enlazar generaciones, encadenar épocas y mostrar fronteras más contiguas (De la Torre, 1943). Escribió Guillermo de la Torre en una época de ebullición antológica que marcará el devenir de la poesía española posterior, pues, recordemos que en 1932 vio la luz Poesía española. Antología 1915-1931, reimpresa y modificada en 1934, bajo el título Poesía española. Antología (Contemporáneos). La primera, de tipo programático (Ruiz Casanova, 2007: 33) y marcada por un carácter generacional, consensuado y parcial, permitió a Gerardo Diego, desde su espacio de relevancia en el campo poético, defender e impulsar determinadas prácticas poéticas. Dos años después, modificó los criterios, ofreciendo una versión panorámica e histórica, tal y como lo explicitó el propio Gerardo Diego en ambos prólogos (Diego, 2007).

Nos interesa esta parte de la historia literaria española, al menos, en dos sentidos. Primero, y siguiendo a Ruiz Casanova, porque fue Guillermo de la Torre uno de los primeros que se propuso un modo crítico para las antologías literarias, aunque no desarrollara el plano teórico con el fin de afrontar la singularidad y el sentido o significado de las selecciones líricas (Ruiz Casanova, 2007: 20). Segundo, porque las antologías de Gerardo Diego, por su relevancia en el panorama de la poesía española del siglo XX, son enormemente significativas a la hora de comprender de qué manera se ha articulado el campo poético posterior. También Claudio Guillén, desde el ámbito de la literatura comparada, pero, a la vez, en la senda abierta por De la Torre, afirma:

La antología es una forma colectiva intratextual que supone la reescritura o reelaboración, por parte de un lector, de textos ya existentes mediante su inserción en conjuntos nuevos. La lectura es su arranque y su destino, puesto que el autor es un lector que se arroga a la facultad de dirigir las lecturas de los demás, interviniendo en la recepción de múltiples poetas, modificando el horizonte de expectativas de sus contemporáneos (Guillén, 1985: $375)$.

No son de extrañar estas palabras, escritas una década después del boom novísimo y en plena efervescencia de los procesos de canonización de las nuevas estéticas surgidas en los ochenta. Tampoco es excepcional que sobre unas reflexiones similares volviera Pozuelo Yvancos unos años más tarde, cuando ya aquellas poéticas que comenzaron a dar sus primeros pasos con García Montero, Egea y Salvador eran las mayoritarias y centrales del campo poético:

El acto de selección del antólogo no es distinto al que preside la construcción de una Historia Literaria, sea ésta de autor individual o colectivo [...] Es más, en el caso de la poesía lírica la impronta de las Antologías ha sido siempre de mayor calado y resulta hoy tan abrumadora que los distintos períodos generacionales y el nombre de algunos de estos períodos, como es el ejemplo de los poetas novísimos, han nacido al calor de una antología concreta" (Pozuelo Yvancos, 1996: 3).

Discurso este que ha sido repetido con pocas modificaciones hasta nuestros días en un claro síntoma de que lo antológico continúa hoy jugando un papel de fundamental importancia: "Es tal el estado de la situación, que aceptamos como natural el hecho de que la poesía española se encuentre en un permanente (y casi compulsivo) estado de antología, como un campo de Agramante donde a veces se libran las más encarnizadas batallas" (González Moreno, 2016: 46). Estas calas nos indican que no estamos ante una opinión de apenas un puñado de historiadores y 
críticos, sino ante una constante cuya existencia puede verificarse a lo largo de décadas. Lo cual, por otra parte, también nos señala que la actuación de los antólogos, en lo que a los objetivos a conseguir con la publicación de las compilaciones se refiere, no debe ser entendida como una actividad que nace de la copia inconsciente de lo que otros con anterioridad hicieron, sino como un hecho plenamente pensado y reflexionado, cuyas consecuencias no son fruto del azar, sino de una voluntad específica:

\begin{abstract}
Algunas, en efecto, nacieron con vocación beligerante o afanes reivindicativos; otras, como plataformas para la promoción de ciertos grupos, movimientos o estéticas; las hay que surgieron como ecos, réplicas o meras prolongaciones de algunas anteriores, o bien para dar proyección a poetas que no la tenían; incluso hubo casos de florilegios que proporcionaron más proyección al antólogo que a sus propios antologados. Incluso otras que solo han pretendido ser faros para guiar al desorientado lector en medio de unas aguas líricas demasiado turbulentas (González Moreno, 2016: 46).
\end{abstract}

La cuestión aquí no debe ser tanto qué antologías han contribuido a la conformación del campo poético en las últimas décadas, hasta la actualidad, como de qué manera lo han realizado, cuáles han sido los mecanismos propagandísticos de los que se han servido (editoriales, prensa, academia, etc.), qué ideologías han defendido los repertorios más canonizados y, sobre todo, por qué. Esto es, en palabras de Walter Benjamin, apuntar al foco del problema, no preguntándose qué relación guarda una obra con respecto a sus condiciones de producción (si está en línea con ellas o aspira a transformarlas y en qué sentido quiere hacerlo), sino cómo está en ellas (qué función tiene dentro de las condiciones literarias de producción de un tiempo) (Benjamin, 1975: 119). Es así como podremos (al menos tratar de) evitar el riesgo de asumir la emergencia de comentarios, críticas y clasificaciones que en el momento de su nacimiento no se discuten, sencillamente porque se les ignora -dice Talens-, pero que pocos años después y por el mero hecho de existir como datos supuestamente objetivos, pueden convertirse en fuentes primarias para los estudiosos e historiadores, sin que necesariamente se cuestione el sistema de valores, esto es, la estructura ideológica y/o política que rodeó su nacimiento (1989: 30). O, en palabras de Juan José Lanz, combatir la falacia (muchas veces aseverada) de "tomar las antologías como hechos empíricos objetivos, lo que en pocos casos son, que reflejarían el panorama poético de un momento y no el gusto particular del antólogo que realiza la antología" (Lanz, 1998: 282).

No podemos obviar, aunque parezca baladí, que toda selección es, a su vez, una exclusión, al igual que hay en toda fotografía un fuera de plano, de tanta o más importancia que el encuadre mismo de la instantánea. Las antologías se construyen sobre la dialéctica memoria-olvido y ello es tan tentador como peligroso: tentador por lo que potencialmente puede provocar su selección en el campo poético; peligroso porque tal poder puede ser destinado a generar una jerarquía o un escalafón que ejecute desde su posición más o menos privilegiada (en determinados casos, por supuesto), un desigual juego de fuerzas en el campo poético, amparado en motivos que, en ocasiones, están alejados de cualquier cuestionamiento crítico (amiguismos, gusto personal, capital económico, etc.). Al fin y al cabo, "la antología poética puede ser el más democrático de los libros, pero lo que es seguro es que es el libro sobre el que mayores tentaciones totalitarias se proyectan" (Ruiz Casanova, 2007: 162). No hay ningún viso de demonización de lo antológico en estas palabras, ni creo que el problema radique en la antología en tanto selección, sino, parafraseando a Méndez Rubio, (2004a: 130) en la inercia acrítica que ese hecho ha supuesto, 
sobre todo cuando el fenómeno se acelera y reitera como lo ha hecho en las últimas décadas. Es entonces cuando "a fuerza de repetir en los medios adecuados que el poema es ansí, finalmente termina siendo entendido precisamente ansí por la mayoría. $\mathrm{Y}$ acto seguido surgen multitudes que no entienden la poesía más que como se les ha dicho que es" (López Merino, 2008: 22). Creo, sinceramente, que la siguiente cita de Juan José Lanz nos puede ayudar a comprender con detalle estas cuestiones:

En primer lugar, la mayor parte de los estudiosos de la poesía española actual conocen a los poetas jóvenes por antologías y no por los libros propios, con lo que sólo conocen su producción poética fragmentariamente, y no en su totalidad, condicionada por el gusto del antólogo. En segundo lugar, muchos antólogos acaban funcionando mecánicamente, seleccionando para sus antologías a aquellos poetas que han sido antologados en obras anteriores, con lo que se produce el famoso efecto «bola de nieve». En tercer lugar, ante tal avalancha de nombres nuevos, las diferencias se difuminan y la calidad de las voces queda oculta entre los ecos de meros poetas epigonales; en definitiva, el bosque impide ver los árboles (Lanz, 1998: 281-282).

Dicho lo cual, no creo que podamos desligarnos de la comprensión de la práctica antológica como un hecho de política literaria de primer orden en el que entran en juego la lucha por el poder, la dialéctica por las premisas del campo poético o las derivas de este, que, en definitiva, impulsan y frenan determinados procesos de canonización. Por consiguiente, este hecho discursivo (en un sentido foucaultiano, como "conjunto de enunciados que dependen de un mismo sistema de formación" [Foucault, 1997: 181]) se constituye como espacio de (re)producción ideológica (en sentido althusseriano, en tanto "representación de la relación imaginaria de los individuos con sus condiciones reales de existencia [1974: 144]) que (re)construye y (re)escribe la historia literaria, la que nosotros, como lectores y ciudadanos, consumimos; la que la crítica genera, también. Todo ello, a partir de un juego más o menos velado de intereses y disputas que, en la actual sociedad del espectáculo (Debord, 2002) y de la información, se ha acercado en sus modos de actuación a los mass media: "la inmensa mayoría de la crítica — tanto la universitaria como la militante- no fotografía o retrata la poesía del momento sino que la perfila y encauza; exactamente del mismo modo que los medios de comunicación no informan sobre la realidad sino que la conforman mediante una premeditada selección e interpretación de hechos" (López Merino, 2008: 11). Sea en la dirección que sea, la práctica antológica, unida a la labor de la crítica que desde todos los medios se ha vertido históricamente sobre el fenómeno (entendida como un modo de "escritura en tanto que lucha ideológica en el interior de la propia ideología hegemónica” [Rodríguez, 1994: 31] que, en la inmensa mayoría de ocasiones, funciona como un microsistema autónomo, tal y como afirmara Ródenas [2003: 145] $]^{5}$ ), han influido en la configuración del campo poético y en la creación de una

\footnotetext{
5 Dice Ródenas: “La opinión de los lectores es irrelevante en el sistema en que opera la crítica, porque es un microsistema autónomo: sólo influye, e igualmente muy poco, entre autores y críticos (o editores) que son quienes recelan, remiran, se llaman, condenan, difaman, difunden y aplazan respuestas y venganzas. Cultivan una chismografía crítica de la que el lector que no sea autor o crítico lo ignora absolutamente todo. No le atañe, aunque le afecta porque es su víctima: el microsistema de la crítica finge hablar al lector cuando de hecho se está hablando demasiadas veces a sí mismo, en un diálogo con mensajeros diversos y un tempo indeterminado (intervienen ahí prólogos, presentaciones, antologías, dietarios, columnismo con negritas, almuerzos, recomendaciones, vetos, frustraciones, de todo, como en el microsistema de los tejedores de hilo fino o los productores de pegamento)" (Ródenas, 2003: 145).
} 
determinada historia literaria oficial 6 . Y ello, por supuesto, es de nuevo una selección. Es tarea de este artículo analizar sus implicaciones, examinar de qué manera ello ha determinado la construcción discursiva del campo poético y averiguar cómo se ha (re)producido hasta nuestros días (o no, ya veremos) esa tendencia que ha tenido un recorrido de enorme importancia en todo el siglo XX.

2. El MODElo Castellet y SUS CONTINUADORES: EL PLEITO DE LAS GENERACiONES Y DE LAS ANTOLOGÍAS

Los cambios de moda y paradigma estético no se producen, o no sólo, por azar ni por generación espontánea, al dictado de un ritmo natural y prefijado que no tenemos potestad para gobernar, sino que están vinculados a decisiones concretas de personas concretas.

Jordi Doce (2005: 286)

Podríamos retrotraernos en este apartado muchas décadas atrás para analizar paso por paso la evolución del "pleito de las antologías". Quizás, estaría justificado comenzar en alguna de las compilaciones publicadas por Gerardo Diego durante los años treinta o, probablemente, en la programática obra de Castellet publicada por Seix Barral en 1962, Veinte años de poesía española, por nombrar algunas de las más canonizadas antologías del siglo XX en España. Creo, sin embargo, que el cambio definitivo de paradigma se dio en 1970: Castellet, que había aprendido de Gerardo Diego la lección de la antología como manifiesto y como estrategia de promoción literaria, y la había puesto en práctica ya en su compendio de 1962 (García, 2017: 55), utilizó de forma más marcada si cabe tales maniobras publicitarias en Nueve novísimos poetas españoles (Barral Editores, 1970), que se convirtió, en palabras de Talens, en la primera antología realizada con anterioridad a la aparición pública de muchos de los nombres incluidos en su nómina, como propuesta de futuro en vez de como selección del trabajo realizado con anterioridad: "no hay crítica sobre los "novísimos" porque existan previamente los novísimos sino que hay novísimos como objeto de estudio porque existe una crítica que habla de ellos" (Talens, 1989: 30)7.

Josep Maria Castellet percibió determinadas ideas de ruptura con respecto a la poesía inmediatamente anterior que se habían estado fraguando a lo largo de los años sesenta y que adquirieron la forma de un enfrentamiento contra la estética que había dominado durante los primeros años de la posguerra hasta bien entrados los años cincuenta (Lanz, 1994: 55), como también señalaran en su momento Falcó y Fanny Rubio (1981: 58) y como detallara Prieto de

\footnotetext{
${ }^{6}$ En el caso de la poesía, como bien ha indicado López Merino "el poder de modelación de la historia de la literatura que la crítica posee es mucho más obvio y efectivo en poesía que en otros géneros, entre otras razones porque la barrera entre poetas y críticos es, desde hace casi un siglo, cada vez más endeble. Hoy día el salvoconducto más efectivo para figurar en la historia de la poesía contemporánea no es ya la obra poética misma sino la presencia que la crítica le otorga" (2008: 1)

7 Castellet recoge en su antología a "Los seniors" (Manuel Vázquez Montalbán, Antonio Martínez Sarrión y José María Álvarez) y a "La coqueluche" (Felix de Azúa, Pere Gimferrer, Vicento Molina Foix, Guillermo Carnero, Ana María Moix y Leopoldo María Panero).
} 
Paula en Musa del 68 (1996: 77-102). “The Times They Are a-Changin”, tituló Bob Dylan en 1964 una de sus más famosas canciones, y no le faltaba razón: Mayo del 68, la Primavera de Praga, el Movimiento por los Derechos Sociales en Estados Unidos, las revoluciones latinoamericanas, las descolonizaciones en buena parte de los países africanos, etc. o, en nuestro caso, un repunte de la oposición interior al franquismo. Todo ello llevó aparejado un renovado interés por determinados objetos culturales, en numerosas ocasiones consumidos en el silencio de la clandestinidad, lo cual generó un caldo de cultivo idóneo para una apertura de la poesía hacia nuevos espacios nunca antes transitados, que incluían la puesta en valor de lo pop y lo camp, la relevancia de los mass media en la formación de los autores ${ }^{8}$ y el auge de los discursos contraculturales que provenían tanto del interior como de fuera de las fronteras españolas, tal y como ha estudiado Germán Labrador (2017) en su reciente Culpables por la literatura. Esa misma efervescencia cultural, atravesaba la poesía de finales de los sesenta (reducto, al fin y al cabo, de la cultura, en el que pocas son las rendijas por las que puede colarse la luz), fue también atisbada por Enrique Martín Pardo en 1967 (Antología de la joven poesía española, publicada en Pájaro Cascabel) y 1970 (Nueva poesía española, en Scorpio) y, principalmente, por José Batlló, que en 1968 coordinó la Antología de la nueva poesía española, publicada en Lumen y, que pese a utilizar y defender términos similares a los de Castellet en 1970, como la emergencia de una novedosa práctica poética que superaba los postulados de posguerra, careció de la habilidad y, quizás, de los contactos necesarios para posicionarse en la primera línea del frente de batalla, en esa lucha por las premisas que se estaba gestando a finales de los sesenta 9 . Así pues, fue finalmente el crítico catalán quien sí pudo hacerlo con sus Nueve novísimos poetas españoles gracias a la amplia presencia de Barral Editores en el entramado editorial del país (ya sustentada y reconocida por la labor realizada con los poetas de lo que Carme Riera [1988] identificó como Escuela de Barcelona), a la imagen pública, principalmente, de Pere Gimferrer y de Guillermo Carnero, y a la relevancia de casi todos ellos en el ámbito de la crítica "con el prestigio que dan por procuración cátedras, editoriales y academias, a las que algunos accedieron pronto" (Prieto de Paula, 2004: 164). En este sentido, "Si el nombre del antólogo no hubiera sido el que es ni la casa editora la que fue, posiblemente el carácter canónico que ha acompañado al libro durante todos estos años no habría existido", dice Jenaro Talens (1989: 30). Todo ello, por supuesto, en el marco de una España tardofranquista, testigo de

\footnotetext{
8 Dice Castellet que este grupo generacional es el primero en España que "se forma íntegramente desde unos supuestos que no son los del humanismo literario, básico en la formación de las generaciones precedentes, sino los de los mass media, aunque en un medio histórico, político y sociológico distinto del de los equivalentes extranjeros" (Castellet, 2011: 20)

9 Sobre las antologías de Martín Pardo (1967) y Batlló (1968), dice Ángel Luis Prieto de Paula: “Son, en realidad, muestras ambas de un estado de cosas en el que se podían percibir, en medio de la nebulosa propia del momento en que se compusieron, signos de cambio. Valga esta sinopsis comparativa: la primera, más atrevida, es un testimonio lógicamente inmaduro de la poesía nueva, en tanto que la segunda es un testimonio maduro de la poesía de la segunda generación de posguerra, con algún añadido de jóvenes autores en la medida en que no rompían el curso poético entonces aún dominante" (1996: 81).
} 
una Barcelona que se estaba convirtiendo en un foco cultural de primer orden y en un punto de encuentro con América Latina ${ }^{10}$.

Esta ruptura con respecto a la poesía escrita en España en los veinticinco años anteriores, convertido en un axioma que no admitía para Castellet discusión alguna y que se fundamentaba en factores derivados del trauma y de las consecuencias de la Guerra Civil (Prieto de Paula, 1996: 87), fue un argumento exagerado por el propio antólogo, tal y como ya indicara el también recopilado Guillermo Carnero (1983: 46). Es cierto, sin embargo, que tal brecha sí tenía un interesante correlato a nivel socio-político y cultural11, puesto que España había comenzado a abocarse a un aperturismo que en poco tiempo le llevaría a participar de las leyes y normas del neoliberalismo y la globalización ${ }^{12}$. En ese espacio todavía en construcción, lo literario fue necesariamente modificado por las circunstancias (tal y como Adorno y Horkheiner habían anunciado al teorizar sobre la "industria cultural" y Walter Benjamin en La obra de arte en la época de su reproductibilidad técnica o como posteriormente constataran, desde posiciones muy diferentes, Louis Althusser en Ideología y aparatos ideológicos del estado y Fredric Jameson en El posmodernismo o la lógica cultural del capitalismo avanzado o, incluso, Terry Eagleton en Marxismo y crítica literaria). Es así como Nueve novísimos consiguió abrir una nueva vía en lo que respecta a la comercialización del producto antológico, integrada ahora en una ideología dirigida por la industria cultural:

Al tiempo, esta polémica resultó paradigmática de un proceso cultural cuyo abandono del realismo corría en paralelo a un experimentalismo literario que, apoyado por la industria editorial, representaba una moda tranquilizadora. Para cuando termina la década de los años sesenta, un amplio sector literario desestimó cuestionar las relaciones capitalistas de base, ya auspiciadas por el régimen. Se entiende, así, el paulatino fracaso estético del modelo del realismo social, tendente a mezclar arte y política, una vez que la mayoría cultural e intelectual había suscrito el giro a una transición democrática de economía capitalista, pues hacer de lo literario el objeto exclusivo de la literatura permitía encauzar el debate hacia aspectos formales, con lo que se naturalizaba - se "ideologizaba"- la función de la estética (Vives Pérez, 2013: 255).

No estamos, en absoluto, hablando de un tema baladí. A partir de la antología de Castellet, y tal vez debido al fulgurante éxito de dicha promoción, acabará imponiéndose una nueva terminología en la que prevalecen, mayoritariamente, las referencias a los conceptos "poesía nueva", "poesía joven” y "poesía última” (González Moreno, 2016: 14) y una nueva práctica

10 La última re-edición de Nueve novísimos poetas españoles en Ediciones Península (Castellet, 2011) profundiza en carácter de acontecimiento cultural que supuso la antología, al incluir un apéndice documental titulado "La crítica. Diciembre de 1969 - febrero de 1971” (2011: 253-285) que recoge fragmentos de algunos artículos de la época, dos cartas de Emilio Alarcos y de Franco Fortini dirigidas a Castellet y la reproducción del documento remitido por el censor del Ministerio de Información y Turismo al editor original de la obra.

11 Castellet, en la justificación de su antología, presenta esta ruptura como una suerte de conflicto, en un ejercicio que a todas luces le permite posicionar su antología en un espacio de enfrentamiento y, por consiguiente, publicitarla en una doble vía: aceptación, por parte de los jóvenes, y rechazo, por parte de los veteranos. En todo caso, propaganda. Dice Castellet: Veinte años de poesía española "había constituido, en cierto modo, un manifiesto generacional de cuyos postulados los más jóvenes poetas disienten radicalmente. Tan radicalmente, que no me ha parecido oportuno darles entrada en una nueva edición de mi libro [...] se diría que se ha producido una ruptura sin discusión, tan distintos parecen los lenguajes empleados y los temas objetos de interés" (Castellet, 2011: 15-16).

12 "Si la crisis del realismo coincidía con la asunción del modelo neoliberal, resultado de la apertura del franquismo a las potencias occidentales, la integración en el capitalismo de los sectores afines al régimen sería motivo de un debate que ahora afectaba a la función poética" (Vives Pérez, 2013: 254-255) 
antológica, que ha atendido con presteza a lo reciente, a la relampagueante actualidad de las generaciones y movimientos poéticos, que se han ido sucediendo y erosionando con una voracidad casi publicitaria (González Moreno, 2016: 16). Así, Nueve novísimos poetas españoles se inserta (e inserta a lo antológico), como objeto cultural, en una dinámica de cambios y modificaciones socio-políticas, de mercado y de industria cultural que, por una parte, la hacen posible y, por otra, permiten que sea lo que ha sido. La publicidad se convierte, parafraseando a Talens (1989), en fuente historiográfica; la actualidad, ahora releyendo a Antonio Méndez Rubio (2012: 34), ocupa el lugar de la historia, en un contexto de Transición marcado por el rechazo de los proyectos críticos, por el olvido colectivo como pacto de convivencia nacional y por una lógica de demanda represiva o política de borradura (Méndez Rubio, 2004b: 31); la aceleración de las sociedades relacionada con el flujo sin trabas y masivo de la información en nuestro tiempo, como dijera Eriksen (extraído de Ramos Torres, 2013: 158), nos traslada a una situación en la que todo amenaza con convertirse en una serie histérica de momentos saturados sin un 'antes' ni un 'después', un 'aquí' y un 'allí' que los separen (de hecho, incluso el 'ahora y aquí' están amenazados, pues los momentos se suceden tan rápidamente que se hace difícil vivir en el presente); todo ello, en un marco de crisis de los relatos utópicos, tal y como las analizaran Lyotard (1984) o Ricoeur (2009), al que se suma un generalizado desencanto (Vilarós, 1998) auspiciado por la asunción de pactos tácitos de silencio y pactos de olvido (Paloma Aguilar, 1996) tras la muerte de Franco. Castellet dio por hecha una generación cuando, de hecho, se estaba todavía construyendo: el proceso en marcha de la antología castelletiana, en el que el fin mismo se une en una suerte de paradoja con los medios utilizados, es un claro ejemplo de un cambio que se avistaba ya en un horizonte no muy lejano y que trasladará la práctica antológica desde la radiografía de lo hecho a la profecía de lo porvenir. Ello nos indica, entre otros detalles, que el campo poético comenzó a re-estructurarse instantes antes del inicio de un nuevo periodo democrático en la historia de España cuyos cimientos, sin embargo, ya habían comenzado a ser construidos:

El supuesto milagro de la Transición consistió simplemente en la adecuación de unas superestructuras de poder a lo que en la base material ya se había dado: la conformación de una sociedad fundamentalmente burguesa, cuya vanguardia, militara en la socialdemocracia o en los centros democráticos, había de ser la gran protagonista y beneficiaria de la Transición y la que aportaría cuadros, cargos y dirigentes a casi todas las formaciones políticas y todos los estamentos de poder, que son la verdadera silueta del establishment democrático (Vázquez Montalbán, 1998: 83-84).

Lo que sucede a nivel político, social y cultural a partir de la llegada de la democracia no hace sino dar la razón a estos argumentos. El poder del discurso oficial, pese al lavado de cara que supuso la Transición, sigue siendo de tal calado que resulta muy difícil escapar de él, hasta el punto de que toda lectura que sobrepase sus límites queda marcada a fuego por la etiqueta de charlatanería radical. Valga como ejemplo la siguiente explicación del 23-F:

En 1981 la desactivación de la cultura es tan grande que ya no se dispone de otra lectura del 23-F que la facilitada por el Estado y por su más alto representante, situación en la que, por otra parte, seguimos esta mañana a primera hora [...] La cultura, sea lo que sea, consiste en su desactivación, es decir, en crear estabilidad política y cohesión social. 
Trabaja, en fin, para el Estado, es el único gestor de la estabilidad y de la desestabilidad desde 1978 (Martínez, 2012: 15-16)13.

La llegada al poder en 1982 del Partido Socialista Obrero Español, que en su congreso de 1979 había abandonado su marxismo fundacional y había decidido moderar su discurso para convertirse en un partido de gobierno (Andrade Blanco, 2005: 50), llevó aparejada una nueva estructuración de la cultura (y, por lo tanto, de la literatura y la poesía): "El Partido Socialista Obrero Español”, dice Jenaro Talens, "durante los años de su mandato, siempre favoreció, en la medida de sus posibilidades (que eran muchas) aquellas propuestas que no problematizaran nada, como si mencionar juntos escritura y política fuera mentar a la bicha" (2005: 148). En esta modernidad sobrevenida, a la que España tuvo que sumarse en apenas unos años, obviando los amplios procesos que marcaron el devenir de otros países europeos, la "Cultura y el Estado trabajan juntos con un fin común: la naturalización y neutralización de los conflictos sociales" (Méndez Rubio, 2012: 132), de forma que las manifestaciones más poderosas de la Cultura (el Arte, el Gusto, la Educación...) "maximizaron su poder gracias a la convergencia funcional con un modelo de estructura política que tenía que jugar públicamente las bazas ideológicas de la igualdad, la libertad y la fraternidad para fundarse como modelo democrático y de progreso. (Méndez Rubio, 2012: 132). Nos encontramos pues, en los años ochenta, con una amortiguación edénica del arte, cuya autenticidad progresista se buscó en máscaras exóticas y horizontes elegantemente realistas que habitaron siempre bajo el signo de un blando y amable neohumanismo (Jiménez Heffernan, 2004: 426). Y ello, en el campo poético, se resumió en una sucesión de promociones que instalaron "su discurrir en el más cuco y acomodaticio universo de la facilidad, la obviedad, la rutina y lo polvoriento mientras se decretaba maldita a la vanguardia (a todo riesgo estético, en general) y se intentaba vetar como anacrónica toda intervención política" (Martínez Sarrión, 2002: 9), dejando de lado "la lección humilde que en el resto de Europa habían dado las vanguardias: que de un mundo en estado crítico solo se puede hacer cargo un lenguaje en crisis" (Méndez Rubio, 2004b: 48).

La emergencia en 1983 de la Otra Sentimentalidad, fundamentada en el marxismo althusseriano de Juan Carlos Rodríguez (1974), y su rápida deriva desde este espacio de intervención ideológica hacia la poesía de la experiencia o de los seres normales, desde los planteamientos radicalmente marxista hacia el horizonte burgués de la Ilustración o desde la utopía revolucionaria hacia la reforma desde dentro de la norma social (Iravedra, 2013: 211), reafirma tales cambios de estructuración del campo cultural y poético en los años ochenta: Luis García Montero (ya establecido en 1988 como cabeza visible de la corriente, cuando Enrique Molina Campos definió por primera vez los postulados de la poesía de la experiencia [Molina Campos, 1988]), y el resto de poetas sumados, supieron leer los objetivos del discurso del poder entre sus propias líneas y plantearon una práctica poética afín a ellos que les permitió alcanzar con presteza los espacios centrales del campo poético: "En la pugna entre los experienciales y los

13 El reciente falso documental de Jordi Évole Operación palace (estrenado en 2014) es otro claro ejemplo de que el relato del golpe de estado está ocultado por una nebulosa que nunca ha dejado atisbar la realidad. Que buena parte de los espectadores creyera durante buena parte del documental la estrambótica versión de los hechos que ofreció Évole, en la que se narra que José Luis Garci ejerció de director de escena de un Golpe de Estado impulsado por los partidos políticos y la corona con el objetivo de reafirmar la recién nacida democracia, es significativo de que todavía hoy existen demasiadas lagunas en el relato del $23 \mathrm{~F}$ y, por ende, de la Transición. 
otros lo que hizo que la victoria cayese del lado de los primeros no fue el número o la calidad de los combatientes a sus órdenes sino su unión, el poder de sus armas, la influencia de sus generales, la estrategia elegida y, por supuesto, cierto aire político favorable" (López Merino, 2008: 38). Es en este preciso instante cuando la corriente figurativa ya se perfilaba como noción dominante, dice Iravedra, y el poeta más carismático de la otra sentimentalidad (Luis García Montero) "asaltaba el canon general de la poesía, apareciendo en las antologías fundacionales de la nueva generación como la cabeza más visible de una revitalización del papel crítico de la escritura, en la estela del experiencialismo de los poetas del cincuenta" (Iravedra, 2017: 203). Lo cual tiene una vinculación con las circunstancias socio-históricas y políticas del periodo, como ha afirmado Antonio Méndez Rubio:

Desde principios de los años 80 del pasado siglo, en España se vivió el cumplimiento de la llamada transición democrática y la llegada al poder político de una socialdemocracia que puso las bases del neoliberalismo actual. Se ha llegado a hablar de los "felices ochenta" para utilizar una expresión que sitúa, por contraste, la depresión colectiva, económica e ideológica, de los 90, que no por casualidad desembocaron a nivel internacional en la llamada "dictadura de los mercados", así como en nuevos conflictos y movimientos sociales de resistencia ante las políticas económicas, laborales y educativas en curso. Esta dinámica de retrocesos ideológicos y vitales corrió paralela a la canonización de una poética realista y narrativa, por lo general descreída y conformista, cuyo tradicionalismo formal se escudó en una denominación ambivalente y totalizadora: se trataba d ela hoy célebre poesía de la experiencia. Este rótulo, poesía de la experiencia, no dejaba de ser en parte una construcción arbitraria y resbaladiza, pero eso no le impidió ser reconocida como una convención de identidad, o como mínimo, de consenso en torno a ciertos principios estéticos e ideológicos comunes (neoclasicismo, individualismo, escepticismo, etc.) (Méndez Rubio, 2008: 168)

Si atendemos a los desarrollos antológicos, ya en 1980 José Luis García Martín hizo primar en Las voces y los ecos a poetas meditativos, temporalistas y neorrománticos, en un compendio tan madrugador que se tiene la sensación de que la doctrina está mucho más consolidada que la propia selección (Mainer, 1998: 26). En sus páginas, el joven crítico utilizaba de nuevo la estrategia de Castellet en 1970, tal y como confirmó Guillermo Carnero al hablar de ella como un "producto de marketing literario, guiado por arbitrarios criterios de camarilla" (Carnero 1983: 52). A partir de este momento, las antologías programáticas de José Luis García Martín, Luis Antonio de Villena y Miguel García-Posada se sucedieron, siempre primando la vertiente figurativa entre sus páginas, hasta el punto de que su selección, parcelación y etiquetado "han resultado ser la versión de la realidad más conocida y repetida por terceros (otros críticos, otros poetas y, si es que no pertenecen ya a las dos categorías anteriores, ciertos lectores)" (López Merino, 2008: 21).

Este mismo ejercicio se dio en Postnovísimos (1986) ("la presentación en sociedad de los nuevos poetas", tal y como afirmara José Luis García Martín [1992: 112]), en la que Luis Antonio de Villena afirmaba que de entre la amalgama de propuestas existentes, es la tendencia de corte clásico, realista y figurativa la que más relevancia tendrá en el futuro próximo de la poesía española, aunque para ello tuviera que forzar la inclusión de diversos autores con la voluntad implícita de aupar a otros: "la estética sustentada por Villena en su estudio prologal se adecua más a un pequeño grupo de los poetas incluidos en ella (Miguel Mas, Luis García Montero, Felipe Benítez Reyes o Leopoldo Alas) que a la totalidad de los poetas allí recogidos y al discurrir estético de la generación en su primera etapa" (Lanz, 1998: 273) en un claro intento de "impulsar 
una de las líneas estéticas precedentes, para hacerla dominante" (Lanz, 1998: 273)14. Hablamos aquí de una selección prospectiva, como ya lo fuera Nueve novísimos, que sugiere o adelante estrategias a las que luego habrían de adaptarse los poetas (Casado, 2005: 28). No es de extrañar, después de lo visto hasta este punto, que este detalle haya dejado de ser la excepción para convertirse en la norma a lo largo de los años ochenta y noventa, tal y como refrendan La generación de los Ochenta (García Martín, 1988), Fin de siglo (De Villena, 1992)15, Selección nacional (Última poesía española) (García Martín, 1995), Treinta años de poesía española (García Martín, 1996) y La nueva poesía española 1975-1992 (García Posada, 1996):

El poder que este estado de cosas confirió a estos críticos es enorme. Desde finales de los años ochenta y durante gran parte de los noventa, todo joven poeta que quisiera aparecer en una antología leída por alguien más que los propios antologados y el antologador, o ser reseñado en un suplemento cultural de tirada nacional, tenía que dirigirse a uno o a varios de estos críticos o de lo contrario resultaba prácticamente imposible que su nombre empezara a sonarle al lector medio de poesía, si es que tal lector existe. Y todos sabemos que un poeta joven es tan maleable como cera a la temperatura adecuada (López Merino, 2008: 22) 16

14 Probablemente, el caso más curioso es el de la inclusión de Jorge Riechmann cuando todavía no había publicado su primer libro, Cántico de la erosión (1987). El perfil combativo de las composiciones de Riechmann incluidas en la muestra ("Amo, luego combato" o "Como necios seguimos esperando...") resulta un contrapunto curioso, al menos al comparar las evoluciones de Riechmann (a partir de su Poesía practicable de 1990) y las de otros antologados, como Luis García Montero o Felipe Benítez Reyes. El propio Luis Antonio de Villena ha afirmado recientemente sobre algunas inclusiones en Postnovísimos: "Conocía también a poetas que me gustaban menos, aunque eran amigos y que iban por otra senda, pues ya sabemos que toda generación -partiendo del mencionado núcleo duro- termina inevitable y buenamente por ser plura. Me refiero a Blanca Andreu, cuyo inaugural De una niña de provincias que se vino a vivir a un Chagall (1981) tuvo notable éxito, o a Jorge Riechmann, entonces muy joven y un tanto obsesionado con la poesía del francés René Char, del que llegó a ser traductor. Los trataba a ambos, pero sus tendencias estéticas me parecían lejos de las de los poetas que mencioné al inicio [Felipe Benítez Reyes, Miguel Mas y José Gutiérrez]" (De Villena, 2016: 43-44). Riechmann queda apartado de los estos compendios, hasta la publicación de La prueba del nueve (Ortega, 1994), que presentó también a poetas "que se entregaban a una exploración crítica de la realidad desde lenguajes no figurativos basados en la fractura del texto" (Iravedra, 2017: 204).

15 Luis Antonio de Villena ya afirmaba en su antología Fin de siglo que la estética estaba a punto de agotarse, que existían figuras epigonales y que por lo tanto podía considerarse esta una antología de cierre (Villena, 1992: 32-33), en una afirmación a todas luces dirigida a la creación de una nueva estética a la que los poetas deberían sumarse. Incluso, Luis García Montero temía una posible deriva hacia una poesía que no consiguiera construir experiencias en el poema, sino que mostrara un vitalismo sin vida y una frivolidad injustificable, es decir, una poesía menor, según sus palabras, fundamentada en la estética de la experiencia, pero incapaz de conseguir, pese a las referencias cotidianas, un efecto de verosimilitud (García Montero, 1993a: 181-182).

16 El propio López Merino analiza con detenimiento la infraestructura del campo poético, como forma de argumentar el porqué de tales acumulaciones de poder, partiendo de las editoriales, las revistas, los encuentros y los premios en los que participan activamente poetas de la experiencia y actores afines a ellos: "Luis Antonio de Villena, José Luis García Martín y Miguel García-Posada, entre otros, antologaron y reseñaron casi única y exclusivamente a poetas afines a esa estética. Que las editoriales de peso (Tusquets, Visor, Renacimiento — dirigida por Abelardo Linares, poeta afín a esa estética—, Comares — dirigida por Andrés Trapiello, poeta afín a esa estética—, algo menos Hiperión —dirigida por Miguel Munárriz, poeta en parte afín a esa estética - y Pre-Textos) y otras menos importantes (la colección «Maillot Amarillo» de la Diputación Provincial de Granada, dirigida por Luis García Montero, adalid y en parte teórico de esa estética) publicaron sobre todo a poetas afines a esa estética. Que muchas de las revistas de literatura con una buena financiación (Renacimiento, Fin de Siglo, Clarín, etc.) estaban dirigidas por autores afines a esa estética (Felipe Benítez Reyes, Juan Lamillar, de nuevo el crítico y poeta José Luis García Martín, etc.) y publicaban mayormente a poetas afines a esa estética. Que numerosos congresos y encuentros de poesía fueron organizados por personas afines a esa estética que invitaban sobre todo a autores, críticos y editores afines a esa estética. Y, finalmente, que casi todos los grandes premios de poesía fueron otorgados a autores afines a esa estética por autores, editores y críticos afines a esa estética" (López Merino, 2008 38). 
Hacia finales de los años noventa, Luis Antonio de Villena publicó 10 menos 30 (La ruptura Interior dentro de la Poesía de la Experiencia), en la que señala una bifurcación: por una parte, un auge del realismo cotidiano, de lo pop y de lo coloquial, que proponían determinadas poéticas cercanas al Dirty Realism anglosajón (con Roger Wolfe como referente principal) y, por otra, una tendencia meditativa de corte esencialista que en gran medida se estaba desvinculando de la anécdota y de la narratividad tan propias de la poesía de la experiencia (Villena, 1997). Luis Antonio de Villena constató una deriva en el seno de la poesía de la experiencia que algunos años después explicitó Ángel Luis Prieto de Paula: la sección más importante de la poesía de la experiencia, dice, "se desplaza hacia un lirismo meditativo, intelectualmente sinuoso y más esencialista, en tanto que otras, minoritarias y dispersas, han quedado sin la fuerza aglutinadora de los nombres mayores, y están embarcadas en una evolución de término impredecible" (Prieto de Paula, 2002: 380). En la misma línea se ha pronunciado Iravedra en el prólogo de Hacia la democracia. La nueva poesía (1968-2000), antología llamada a marcar una época en la historia de la poesía española en la que tituló un apartado del extenso prólogo «El ocaso de la experiencia: sendas de la ruptura interion» (2016: 115-127). En sus páginas, profundiza de nuevo sobre estos aspectos, que ya ella había sobrevolado en otras investigaciones (2008, 2010 y 2013). Ahora bien, pese a lo aparentemente novedoso de la propuesta, las poéticas seleccionadas ofrecían un panorama similar al de las antologías anteriores, matizado con algunos nombres más jóvenes y menos recurridos (Juan Carlos Abril o Carlos Pardo, por ejemplo), que no señalaban tanto una fractura, sino una nueva inercia meditativa en el seno de la poesía de la experiencia, una suerte de "avance sin ruptura del modelo experiencia, que buscaría huir de sus clichés formales y temáticos sin renunciar a la esencia de su ideario estético" (Iravedra, 2017: 212), tal y como también explicitara el propio antólogo en unas declaraciones a El País: "Son poetas, todos ellos, realistas, que parten de la experiencia, secuelas de gente como García Montero, Felipe Benítez o Carlos Marzal, y que van evolucionando" (Goñi, 1997).

El caso de La generación del 99, de José Luis García Martín es similar. Pese a la inclusión de voces más jóvenes, como las de Luis Muñoz, Ana Merino, Andrés Neuman, o Carmen Jodra Davó, entre otras y otros, junto a las de los ya canonizados Benjamín Prado, Aurora Luque, Vicente Gallego o Jesús Aguado, el antólogo, que se mantuvo impertérrito al jaleo y fiel a sí mismo, ofreció en este volumen la más pura y joven poesía figurativa (López Merino, 2008: 28)17: "solo en el realismo frío de Pablo García Casado hallamos una propuesta de compromiso que entronca con los modos más genuinos del realismo sucio anglosajón y de su propulsor en España" (Iravedra, 2017: 216). García Martín atiende, de nuevo, a ese carácter prospectivo, ya normalizado en estos compendios, tal y como podemos comprobar con afirmaciones como las que siguen: "el buen antólogo es el que acierta a encontrar los que acabarán convirtiéndose en presencia obligada en cualquiera de los textos que se ocupen del período" (García Martín, 1999: 16) o "La generación del 99 [...] no pretende definir una generación poética [...] ni establecer la nómina cerrada de sus integrantes; no es una imposición del antólogo, sino una cortés invitación:

\footnotetext{
${ }_{17}$ El propio García Martín dice: "he leído y releído la mayor parte de la obra de unos cientos de poetas jóvenes y he procurado prescindir, en la medida de los posible, de razones de amistad o afinidad a la hora de antologar los que me parecían más verdaderos y personales” (1999: 18). Pese a su intento por justificar la selección, entenderá rápidamente el lector que los criterios de "verdaderos y personales" quedan muy alejados de los argumentos críticos que, sin duda, deberían regir las antologías.
} 
estos son, a mi entender, los más notables de los nuevos poetas; pasen y lean” (García Martín, 1999: 30). Curiosa afirmación si tenemos en cuenta que el concepto generación aparece ya en el título mismo de la antología.

Es posible hablar, entonces, de una definitiva "victoria de los realistas" en el campo poético de la España de los noventa, tal y como lo avanzara Mainer (1999:31), fundamentada en una crítica sin cuartel hacia los experimentalismos y las poéticas de herencia vanguardista. Las antologías vinieron a escribir, utilizando la cita de Falcón con la que abríamos este apartado, la historia de la poesía española y fueron, de hecho, y por retomar la cita de Jordi Doce, decisiones concretas de personas concretas las que provocaron tales derivas:

Los críticos mencionados publicaron sus antologías en editoriales importantes (Villena en las influyentes Visor y Pre-Textos; García Martín en Júcar, en Renacimiento y en la más modesta Llibros del Pexe; y García-Posada en la prestigiosa colección de clásicos de Crítica). Publicaron también sus reseñas primero en periódicos de tirada nacional (El País, El Mundo) o en revistas de poesía solventes y con verdadera distribución (Renacimiento, Fin de Siglo, Clarín, etc.) y, después, reunidas en libro, en las mismas editoriales que publicaron sus antologías (López Merino, 2008: 39)

Sucede, por lo tanto, que el discurso cultural de la España postransicional (hasta nuestros días) generó un modelo que ha favorecido la profusión de los ecos sobre las voces y el seguidismo más chato con respecto a los inmediatos predecesores, en palabras de Jordi Doce: "si estos han tenido la suerte de ser incluidos en la foto generacional, el camino más seguro hacia ese principio de canonización provisional implica, sin duda, mimetizar sus maneras (Doce, 2005: 299). Y estas maneras son, en gran medida, aquellas que señalaron los compendios antes citados: no se escribía ni se publicaba más poesía de la experiencia que de cualquier otro tipo, dice acertadamente (López Merino, 2008: 58), sino que los principales antólogos antes citados recopilaron y reseñaron casi única y exclusivamente poetas afines a la tendencia, las editoriales de peso (Visor, Tusquets, Renacimiento y, en menor medida, Hiperión y Pre-Textos) lanzaron al mercado los libros de estos, las más importantes revistas literarias estaban dirigidas por ellos y publicaron en gran medida composiciones de corte experiencialista, los congresos y encuentros fueron organizados por críticos y poetas cercanos al marbete y, finalmente, casi todos los grandes premios fueron otorgados a autores afines a la estética (López Merino, 2008:58). Lo más significativo de todo ello, en la línea de lo que en este artículo queremos destacar, es que estos procesos de canonización estuvieron en gran medida definidos por las antologías. Ahora bien, hubo, por supuesto, respuestas.

\title{
3. LA LUCHA POR LAS PREMISAS EN LOS MÁRGENES DEL CAMPO: FEROCES, CRÍTICOS Y DISIDENTES
}

\author{
Si hacían daño las relaciones sociales y económicas \\ establecidas, ¿cómo se podría decir sí a las mismas \\ relaciones poéticas establecidas? \\ Juan Carlos Rodríguez (2016: 16)
}

Las formas más convencionales del credo realista, dice Méndez Rubio (2004b: 40), siguen ocupando una posición dominante en el escaparate institucional: "y esto no sólo por la recurrencia de títulos y autores en esa onda, sino ante todo, por la forma que sus defensores 
tienen de entender las relaciones con la alteridad, no en clave de diálogo autocrítico sino en clave de propaganda y dogmatismo" (Méndez Rubio, 2004b: 40). El campo poético español de las últimas décadas, visto lo visto, se ha construido sobre la defensa de las poéticas figurativas cercanas a la poesía de la experiencia, en buena parte desde las páginas de las antologías mayoritarias y dominantes antes referidas, y del aparataje crítico que se desarrolló a su alrededor (reseñas en diarios, revistas, etc.). Sucedió, al menos, en una doble dirección: primero, a partir de argumentos como el de la necesidad de escribir una poesía dirigida a los seres normales, utilizado por García Montero (1993b), para retomar así, supuestamente, un humanismo perdido; segundo, criticando duramente todas aquellas prácticas poéticas que se fundamentaron en tradiciones vanguardistas o que manifestaron abierta y explícitamente unas premisas ideológicas de cariz revolucionario (como fue el caso de las llamadas poéticas de la conciencia crítica que, en los años noventa construyeron diferentes espacios de debate y discusión: Alicia Bajo Cero, la Unión de Escritores del País Valenciano, Voces del Extremo, el Ateneo Obrero de Gijón, etc.).

Ahora bien, si de lo que aquí se trata es de analizar los juegos de fuerzas en el campo poético para discernir finalmente qué está ocurriendo en la actualidad y qué ha ocurrido en ese espacio de (casi completo) vacío crítico que es el de los últimos quince años de poesía española joven (desierto en el que este monográfico quiere adentrarse), es necesario focalizar, aunque sea brevemente, en las antologías que se publicaron desde espacios exteriores al centro, ya copado por las poéticas de la experiencia.

Resulta curioso que para elaborar una genealogía de estas "disidencias", debamos comenzar con aquella primera propuesta programática de una generación emergente a principios de los ochenta: La otra sentimentalidad, publicada en 1983, en la que Egea, Salvador y García Montero presentaron una nueva práctica materialista de la poesía a partir de textos teóricos, manifiestos y poemas. Ahora bien, pese al carácter "rupturista" con respecto a la poesía inmediatamente anterior, no cabe duda de que también nos encontramos en este caso con una puesta en marcha de una estrategia propagandística que, vistos los resultados más de treinta años después, permite hacer nuestras las palabras de Amorós: "no los supera ni Castellet" (1989: 65). Estamos hablando de la relevancia pública de García Montero tras la consecución del Adonáis, del impulso que les permitió la publicación del manifiesto en El País, del apoyo del PCE y de Rafael Alberti, del apoyo municipal y autonómico, etc. Esto es, de toda una serie de factores que excedieron (y en ocasiones complementaron) la propia práctica poética y que fueron, en definitiva, las herramientas puestas en juego por instituciones, instancias y personas concretas para aupar una determinada poética. La otra sentimentalidad no fue una obra de referencia histórica a la manera de Nueve novísimos poetas españoles, es decir, no generó un discurso tan abarcador como lo hiciera el compendio de Castellet, sino una antología cuya importancia se debe, más bien, a las posteriores derivas (principalmente de Luis García Montero) hacia un espacio creativo que pronto abandonó las lecciones materialistas de Juan Carlos Rodríguez (y, por ende, de Althusser y de Manuel Sacristán) para abrazar los postulados experienciales de la "cotidianización de la poética" (Rodríguez, 1999: 289), amparada en "el cultivo de una épica subjetiva fundada en la proyección de lo privado sobre lo público" (Iravedra, 2013: 206). Muy probablemente, este desplazamiento fuera causado por la dificultad de sujetar la práctica poética, forzosamente enraizada en la experiencia cotidiana, a los rigores de una teoría que exigía desenmascarar lo invisibilizado de un complejo entramado social (Iravedra, 2010: 31). Sea como sea, la Otra 
Sentimentalidad se ahogó en su propio aparato teórico al no generar unas poéticas afines a los planteamientos rupturistas y heterodoxos, de base althusseriana, defendidos en diversos artículos y ensayos, sino en consonancia con el establishment político-social de los años ochenta. Así, esta antología, de gran relevancia contestataria a principios de los años ochenta (una suerte de pequeño islote en un archipiélago inmenso de masas de tierra), ha acabado por devenir en una suerte de momento iniciático a partir del cual comprender las posteriores inercias de lo experiencial en el campo poético de la España inmediatamente posterior a su publicación.

A estos mismos tres nombres se sumaban los de Benjamín Prado, Javier Salvago y Antonio Jiménez Millán en 1917 versos, publicada por Vanguardia Obrera para conmemorar el setenta aniversario de la Revolución Rusa. Benjamín Prado ponía de relevancia en el prólogo el componente marcadamente político de la antología, a la vez que revitalizaba y reactualizaba los principios más relevantes de la otra sentimentalidad "en un momento en el que, de hecho, los supuestos de aquel programa se habían diluido en el cauce muy elástico de la poesía de la experiencia" (Iravedra, 2017: 202-203). La antología, sin embargo, tuvo y ha tenido poco recorrido, más allá de lo anecdótico que desde hoy nos resulta la inclusión de tres nuevos nombres que con posterioridad han sido fundamentales en los procesos de canonización de la corriente experiencialista. En 1987 las cartas ya estaban sobre la mesa: recordemos, por ejemplo, que Enrique Molina Campos acuñó el término poesía de la experiencia en un artículo de 1988. Queda así, pues, 1917 versos como una de las últimas (si no la última) antología marcadamente política del ya ampliado núcleo granadino, un último brindis al sol apenas instantes antes de la aceptada y planificada inercia hacia lo experiencial.

Pero sin duda, si en este periodo hay una antología de referencia para percibir las prácticas poéticas que trabaron un diálogo crítico de amplio calado contra la mayoritaria poesía de la experiencia, esa es Feroces. Radicales, marginales y heterodoxos en la última poesía española, coordinada por Isla Correyero y publicada en 1998 por DVD Ediciones. A lo largo de sus más de cuatrocientas páginas, aúna las voces de poetas posteriormente ubicados en el amplio marbete de la "poesía de la conciencia crítica" (García-Teresa, 2013) cuyas obras fueron habitualmente apartadas de los cauces editoriales de mayor calado en los que se movieron las antologías analizadas en el apartado anterior. Hablamos de Jesús Aguado, Graciela Baquero, Violeta C. Ranjel, Enrique Falcón, David González, Antonio Méndez Rubio, Antonio Orihuela, Eladio Orta, Isabel Pérez Montalbán, Jorge Riechmann o Miriam Reyes, entre otras y otros ${ }^{18}$. La voluntad de Isla Correyero fue la de dar cuenta de unas vertientes creativas otras, si no enfrentadas sí al menos diferenciadas de las propuestas poéticas de la poesía de la experiencia, ya cómodamente asentadas en la "autocomplacencia de un sujeto cómodamente recluido en el reducto de su privacidad, ajeno y a la postre tácitamente conforme con los patrones sociales vigentes" (Iravedra, 2007: 143). De lo que aquí se trata es de hacer una selección de toda una vorágine de nombres que han buscado (y buscan) situar a partir de poéticas muy diferentes el conflicto de la actual coyuntura histórica en el centro y eje (implícita y explícitamente) de su creación poética, manifestándolo «de una forma estructural, orgánica dentro de su obra, como

\footnotetext{
18 Muy probablemente, los únicos nombres compartidos con los compendios antes citados sean los de Juan Antonio González Iglesias y Pablo García Casado, además, por supuesto, de Jorge Riechmann, incluido, como hemos visto, en Postnovísimos.
} 
base de su percepción de la realidad, del entorno, de los otros y de sí mismo; como principio básico en su estructura poética» (García-Teresa, 2013: 10-11). Para ello, se tienen en cuenta muy diversas formulaciones retóricas, desde el testimonialismo disolvente situado en la esfera del realismo sucio (David González o Pablo García Casado), a la experimentación lingüística extrañada y combativa con el lenguaje de los pactos (Antonio Méndez Rubio, Enrique Falcón o un Jorge Riechmann a caballo entre la estética de la pobreza y un realismo de indagación), pasando por la expresa condena del orden establecido encauzada a partir de registros hiperrealistas cercanos a la antipoesía (Eladio Orta, Antonio Orihuela o Isabel Pérez Montalbán) (Iravedra, 2017: 206).

Heredera de esta compilación es Once poetas críticos en la poesía española reciente (Falcón, 2007), fundamentada en la idea de que "ni la literatura es una estructura inocente ni en la actualidad existe posibilidad alguna de poner en marcha una práctica emancipatoria significativa si no es sobre la base de una simultánea transformación cultural" (Falcón, 2007: 7). En sus páginas se dan cita el propio Enrique Falcón, junto a Jorge Riechmann, Daniel Bellón, Isabel Pérez Montalbán, David González, Antonio Orihuela, Antonio Méndez Rubio, Miguel Ángel García Argüez, David Franco Monthiel, David Eloy Rodríguez y José María Gómez Valero, quienes, parafraseando al antólogo, son suficientemente significativos como para dar cuenta de diversos proyectos de escritura resistente: "la que anuda (eso sí: gradualmente y sin marcar excesivas separaciones) un latido crítico de pretendida ruptura y transgresión del lenguaje y otro tipo de retóricas pretendidamente más transparentes donde una noción plana de realismo podría sin embargo resultar agujereada en más de algún aspecto" (Falcón, 2007: 9). De nuevo, Falcón incide en la pluralidad de las estéticas recopiladas, como ya hiciera Correyero, para destacar, finalmente, en una crítica velada a las poéticas experiencialistas, que "de ninguna de estas opciones, sin embargo, cabría deducir que lo personal y lo político pudieran constituirse como esferas separadas, por mucho que el discurso neoliberal imponga falsamente en nuestro tiempo una brutal separación entre lo público y lo privado" (Falcón, 2007: 10).

La dispersión estética que ambas antologías defienden es a todas luces una de las más marcadas diferencias con respecto a las antologías analizadas en el apartado anterior. Si recordamos, hablábamos de muchas de aquellas a partir de su carácter prospectivo: el antólogo plantea una estética, incluye a poetas que la orbitan y espera que ello tenga una continuidad que validará en un futuro (o no) sus apreciaciones y que nuevas voces se sigan la senda marcada. El caso de Feroces y de Once poetas críticos es bien distinto, puesto que su voluntad es la de recopilar, sin ánimo de establecer una pauta generacional, a poetas cuyas propuestas poéticas orillan la concepción del poema en tanto elemento de participación en el desarrollo histórico y material de los acontecimientos y que, en palabras de Falcón debe acompañar a los "procesos materiales de acción política (siendo éstos los únicos dotados de potencial transformador, y no sólo en lo simbólico)" (Falcón, 2010: 29) o, en palabras de Alicia Bajo Cero al "asociacionismo como acción crítica de grupo" (Alicia Bajo Cero, 1996: 16). Tampoco Once poetas críticos buscó en su momento crear una corriente poética a la que pudieran sumarse otras y otros autores, ni persiguió la formación de una generación marcada por unas pautas determinadas. Más bien, se planteó con la voluntad de dejar constancia de determinadas prácticas poéticas disidentes y disconformes, importantes sin duda pese a su trabajo desde la oscuridad y la ceguera (Méndez Rubio, 2004b: 15), cuya explícita voluntad crítica con respecto a los discursos oficiales y centralizados del campo poético les valió un acalorado rechazo por parte de los canonizados poetas de la experiencia en 
esta "nueva lucha por la hegemonía” (Méndez Rubio, 2004b: 23). Así pues, estas antologías debieron conformarse con ocupar un espacio periférico en los juegos de fuerzas del campo poético español: primero, porque no fueron (ni quisieron ser) refrendadas por los grandes sellos editoriales y, por lo tanto, no tuvieron la difusión que sí marcó la deriva de las anteriores; segundo, porque en un panorama que claramente ha abogado por el modelo generacional del etiquetado, fundamentado en la existencia de unas pautas comunes que los diferentes poetas del marbete siguen fielmente en sus escritos, ambas antologías dirigen su discurso no a la creación de una nueva corriente alternativa, heterodoxa o disidente, sino a la compilación de una serie de poéticas variadas con pequeños (pero muy relevantes, eso sí) puntos de contacto; tercero, porque en un marco cultural en el que "sólo es posible escribir determinadas novelas, discursos, artículos, canciones, programas, películas, declaraciones, sin salirse de la página o ser interpretado como un borrón" (Martínez, 2012: 14), las prácticas poéticas recogidas en ambas compilaciones buscaban una efectiva modificación de las estructuras sociales, no tanto a partir de sus escritos (al fin y al cabo, eran conscientes de que un poema por sí mismo no tiene valor ni poder) sino a partir de las acciones que esos versos podían acompañar, siguiendo la máxima de Bourdieu que el propio Falcón utiliza como apertura de la antología:

Los escritores y los artistas podrían desempeñar, en la nueva división del trabajo político, o, para ser más exactos, en la nueva manera de hacer política que hay que inventar, un papel absolutamente insustituible: dar fuerza simbólica, a través del arte, de las ideas, de los análisis críticos; y, por ejemplo, dar una forma visible y sensible a las consecuencias, todavía invisibles, pero científicamente previsibles, de las medidas políticas inspiradas en las filosofías neoliberales. (Bourdieu, 2001: 45) ${ }^{19}$

De similares características es Disidentes. Antología de poetas críticos españoles (1990-2014), de Alberto García-Teresa, publicada en La Oveja Roja, con la única diferencia de que su discurso y su amplia selección recoge a poetas desde Jesús Lizano (nacido en 1931 y fallecido en 2005) hasta Enrique Martín Corrales (nacido en 1992), en un intento de apertura del panorama hacia las más nuevas y recientes voces. Por ello, hemos decidido analizarla en el siguiente apartado.

Sea como sea, el desplazamiento de estas antologías hacia espacios no centrales del campo poético es un claro síntoma de que "hay en lo poético un peligro, una especie de amenaza difícil de advertir, que sin embargo resulta extrañamente impropia para el estado de cosas" (Méndez Rubio, 2004b: 14). Habitamos, como hemos dicho en repetidas ocasiones, un espacio atravesado por una ideología que responde a los presupuestos de la Cultura de la Transición y que ha generado "unos pentagramas canijos, estrechos, en los que sólo es posible escribir determinadas novelas, discursos, artículos, canciones, programas, películas, declaraciones, sin salirse de la página o ser interpretado como un borrón. Son unos pentagramas, por otra parte, formulados para que la cultura española realizara pocas formulaciones. (Martínez, 2012: 14). En ese marco sociopolítico, no es de extrañar que las prácticas poéticas recogidas en estas antologías fueran recibidas bien con el silencio de la crítica oficialista (no hay mejor desprecio que no hacer aprecio, apunta tan acertadamente la sabiduría popular), bien con su rechazo. Al fin y al cabo, en este espacio en

\footnotetext{
19 Así lo demuestran las obras publicadas por la Unión de Escritores del País Valenciano y Alicia Bajo Cero en el sello Ediciones Bajo Cero en colaboración con diversos colectivos: Textos por la insumisión, junto al Movimiento por la Objeción de Conciencia, en 1992; Taller de escritura: El lugar de reencuentro, junto a las Madres de la Plaza de Mayo, en 1995; y La mirada urgente (textos contra el racismo), junto a Valencia Acoge, en 1995.
} 
el que la Cultura trabaja para el Estado ("Culture is not a mere supplement to the state but the formative principle of its efficacy. It is, in other terms, a principal instrument of hegemony" [Lloyd y Thomas, 1997: 118]), un objeto cultural únicamente es reconocido públicamente cuando no colisiona con él, es decir, cuando no se inserta en la zona de lo problemático (formal o de contenido), en la que por otra parte se ha producido gran parte de la cultura europea de los últimos cien años (Martínez, 2012: 15-16). Así, para cerrar este apartado, podemos traer a colación unas palabras de Méndez Rubio que dialogan con las anteriormente citadas de Bourdieu y que despiertan decenas de cuestiones al respecto de lo dicho en este apartado:

De hecho, en nuestras sociedades contemporáneas de la desaparición, donde el uso sistemático de la propaganda y la publicidad convierten las formas oficiales de cultura en sutiles mecanismos de ocultación, de negación de existencia, creo que el mayor desafío del poeta debería consistir en dejar constancia de lo que no (se) vio [...] Se trata, pues, de un recorrido crítico, inseguro, por las zonas de silencio creadas por las deslumbrantes proclamas institucionales al uso -políticas, culturales, literarias... (Méndez Rubio, 2004b: 36)

\title{
4. ¿Pueden hablar los Nacidos EN LOS OChenta?
}

\author{
"Hijos de la bonanza", nos llamaban \\ Ben Clark (2006: 16)
}

La apertura del campo poético a las nuevas voces nacidas en los ochenta (las cuales son objeto de este monográfico) se produjo en los primeros años del siglo XXI. En opinión de quien escribe, estas iniciales bocanadas de aire fresco comenzaron en 2002. En este momento, ya han sido consolidados algunos autores de las recientes inercias meditativas (surgidas a partir de las poéticas experiencialistas) como Luis Muñoz, Juan Antonio González Iglesias o Ana Merino; también, buena parte de los posteriormente llamados poetas de la conciencia crítica nacidos en los sesenta y los setenta que comenzaron a publicar hacia finales de los ochenta o ya en los años noventa, como Antonio Méndez Rubio, Enrique Falcón, Antonio Orihuela, Isabel Pérez Montalbán, Jorge Riechmann o David Eloy Rodríguez; y, finalmente, aquellos hijos de los setenta difícilmente clasificables, como Andrés Neuman, Ariadna G. García, Luis Bagué, Álvaro Tato o Juan Antonio Bernier. Así, 2002 es el año de una necesaria renovación, si no en las estéticas sí, al menos, en los nombres. Y precisamente lo digo porque es entonces cuando publicaron sus primeros poemarios dos jóvenes autores: Elena Medel (1985), que gracias al Premio Andalucía Joven pone en circulación Mi primer bikini en DVD, y Fernando Valverde (1980), que ve editado Viento favorable, en la editorial de la Diputación Provincial de Huelva, merced al Accésit del Premio Hispanoamericano de Poesía Juan Ramón Jiménez.

Mi primer bikini era la obra "de una adolescente de dieciséis años, precoz y sorprendente, descarada y segura de sí misma, pero de voz inmadura al fin y al cabo, aún por hacer en muchos aspectos" (Salas Díaz, 2007: 93), que se articula como una "interesante exploración de la adolescencia con la ayuda del simbolismo y del surrealismo, fundiendo el culturalismo con otras estéticas postnovísimas en una voz extraordinariamente propia” (Quesada, 2015: 1) y en cuyos 
versos Medel "pretende quebrar la vida para que asome la belleza y disfrutar siempre trabajando con el lenguaje" (Quesada, 2015: 2).

Viento favorable, por su parte, es un poemario también adolescente, propio de quien tiene mucho que decir y mucho que pulir, y que ha sido leído como una renovación de la nueva sentimentalidad en el siglo XXI (Morales Lomas, 2017: 128) y como una suerte de continuidad con respecto al paradigma experiencial y a su inercia meditativa de finales de los noventa: "con sitio consolidado en la estela figurativa, percibimos en la voz de Fernando Valverde rasgos como el referencialismo, la introspección meditativa y una sugerente aportación de imágenes que permite una remozada interpretación simbólica de la realidad. El hablante verbal suele ubicarse en el cruce que une el latido inestable del presente y la intrahistoria concreta" (Morante, 2016: 12). El poeta confía en la eficacia estética de los contenidos (Morante, 2016: 12), pues, al fin y al cabo, es la Universidad de Granada su alma máter y el espacio donde comienza a especular con lo poético:

No podemos obviar en su ya largo recorrido su formación universitaria en la Facultad de Filosofía y Letras de Granada, ni el haber sido discípulo de profesores como Juan Carlos Rodríguez Gómez, el relevante ideólogo de la poesía de la nueva sentimentalidad, y de poetas y profesores tan influyentes en los últimos años del siglo XX como Luis García Montero, que llevó a la práctica lírica esta forma de construcción poética que acabó convirtiéndose en un referente de la lírica de finales del XX (Morales Lomas, 2017: 128)

Si analizamos sus recorridos hasta el presente, no podemos más que constatar que ese año 2002 vio nacer la voz de dos poetas que han sido ampliamente reconocidos por la crítica y que han conseguido gracias a ello ocupar los principales espacios de difusión, tanto si atendemos a los poemarios publicados, como a las antologías en las que han sido incluidos. En este sentido, Fernando Valverde, tras la publicación de Madrugadas en la granadina Cuadernos del Vigía (2003), dio el salto a Visor con Razones para buir de una ciudad con frío, gracias al Accésit del Premio Fray Luis de León en 2004, y allí se mantuvo con Los ojos del Pelícano en 2010, Premio de Poesía Emilio Alarcos Llorach (que, además, ha sido editado en Costa Rica, México, Colombia, Argentina y, traducido, en Estados Unidos). Elena Medel, por su parte, publicó Tara en la barcelonesa DVD Ediciones en 2006 y, tras varias plaquettes y cuadernos, consiguió publicar Chatterton en Visor en 2014, gracias al reconocido Premio Loewe. Ambos, además, poseen ya sendas ediciones de sus obras completas en la prestigiosa editorial madrileña: Un día negro en una casa de mentira (1998-2014), llevan por título las de Medel; Poesía (1997-2017), la de Valverde. No fue, es cierto, la de 2002 una atronadora entrada en la maraña de nombres del panorama poético, sin embargo, el tiempo y las derivas en estos últimos quince años parecen darnos la razón al pensar que en esos meses no solo tuvimos que aprender que un Euro eran ciento sesenta y seis pesetas, sino también que existía ya un hálito rejuvenecedor en la poesía española del nuevo milenio.

Ahora bien, si 2002 es el inicio de la apertura, 2006 es el año en el que los nacidos en los ochenta abren definitivamente las puertas del campo. Si Valverde y Medel lo hicieron sin demasiada algarabía, Ben Clark (1984) y David Leo (1988) lo hacen de forma escandalosa al ganar ex aequo el XXI Premio de Poesía Hiperión con Los hijos de los hijos de la ira y Urbi et orbi respectivamente: "desde posiciones estéticas diferentes, y con una alta calidad de escritura en ambos casos, los autores coinciden en expresar el desasosiego de una generación emergente en la 
actual poesía española", en palabra de un heterogéneo jurado formado por Jesús Munárriz, Francisco Castaño, Luis García Montero, Almudena Guzmán, Carlos Piera y Jenaro Talens (Europapress, 2006) que, desde sus diferentes posiciones estéticas e ideológicas supo reconocer ambos poemarios.

En este caso, los dos recorridos muestran claras divergencias. Mientras que Ben Clark ha continuado con una carrera poética muy amplia, con títulos como Basura (Editorial Delirio, 2011), Los últimos perros de Shackleton (Proyecto Literal, 2013, y Editorial Sloper, 2016), La fiera (Sloper, 2014) y La policía celeste (Visor, 2018; Premio Loewe), David Leo ha tenido mucha menos estabilidad, con apenas algunas apariciones en antologías y pocos poemarios publicados, como Dime qué (DVD, 2011). En cualquier caso, los versos existenciales de Ben Clark (herederos del Dámaso Alonso de Los bijos de la ira), indagatorios y críticos, en los que habitan los tópicos atemporales (como el amor o el discurrir del tiempo) y los avatares de una sociedad tecnológica que ha diseñado unas complejas relaciones entre el ser urbano y los entornos naturales (Morante, 2016: 24), esos versos, decía, que dan sus primeros pasos en Los hijos de los hijos de la ira son definitorios de buena parte de la última poesía. Ben Clark es, de alguna forma, referente, y su cita más reproducida de aquel primer libro es, en gran medida, el rótulo que agrupa a toda una generación (no solo de poetas, sino de individuos nacidos en torno a los años ochenta y noventa): "Los hijos de los hijos de la ira / herederos de todos los despojos" (Clark, 2006: 16).

A nivel antológico, estos poetas de los ochenta y los noventa comenzaron a transitar a partir de 2003 algunos compendios, todavía firmados por los ya canonizados nombres del campo poético, y lo han continuado haciendo hasta nuestros días. Elena Medel, por ejemplo, fue incluida en La lógica de Orfeo (Villena, 2003), en 25 poetas jóvenes españoles (VVAA, 2003), en Última poesía española (Morales Barba, 2006), en Deshabitados. Antología de poesía española joven (Abril, 2008), en La inteligencia y el hacha (De Villena, 2010), en Heterogéneos (González y Boix, 2011) y, más recientemente, en El canon abierto: última poesía en español (1970-1985) (Sánchez García y Geist, 2015) y en Fugitivos. Antología de la poesía española contemporánea (Aguado, 2016). También la obra de Fernando Valverde está recogida en esta última antología, así como en Poesía para la incertidumbre (Antología) Nuevos poetas en español (VVAA, 2011) (de la que él mismo, en gran medida, fue impulsor) y en Humanismo solidario. Poesía y compromiso en la sociedad contemporánea (Sánchez García y Bianchi, 2015). David Leo, por ejemplo, apareció junto a Medel en La inteligencia y el hacha (De Villena, 2010). Ben Clark, por su parte, ha sido incluido en antologías temáticas bastante variadas y, a su vez, en la panorámica Heterogéneos (González y Boix, 2011). Probablemente, el nombre más recurrente en estas compilaciones que no ha sido nombrado en este apartado sea el de Fruela Fernández (1982), cuya obra fue recogida en La lógica de Orfeo (De Villena, 2003), Última poesía española (Morales Barba, 2006). Deshabitados. Antología de poesía española joven (Abril, 2008) y La inteligencia y el hacha (De Villena, 2010), pero que no ha tenido una presencia tan constante como la de Fernando Valverde, Elena Medel y Ben Clark en los últimos años de práctica antológica. 


\section{EL CASO LUNA MiGUEL Y LOS INSTANTES INICIALES DE UN ¿NUEVO? PARADIGMA ANTOLÓGICO}

Una de esas cajas que se mandan al futuro para ver cómo éramos en los años diez del siglo XXI.

Elena Cabrera (en Miguel, 2011:142)

Sin Fernando Valverde y Elena Medel en 2002, sin Ben Clark y David Leo en 2006 y sin la inclusión de estos y otros nuevos nombres en algunas de las antologías anteriormente citadas, no podemos entender lo que supuso el fenómeno Luna Miguel cuando en 2011 se publicó Tenían veinte años y estaban locos, la primera antología coordinada por una joven poeta en la que únicamente se recogían las voces de otras y otros jóvenes nacidos después de 1980 (tal y como marcan las líneas de este monográfico ${ }^{20}$. Tampoco es posible comprenderlo sin tener en cuenta lo dicho en los apartados anteriores sobre las derivas y la importancia del hecho antológico en las últimas décadas y, por supuesto, sin ser conscientes del auge de las redes sociales, en tanto herramienta de difusión y conexión. Al fin y al cabo, Tenían veinte años y estaban locos brota de un Tumblr creado por Luna Miguel en 2010:

A casi todos los autores los conocí o los leí por primera vez a través de la pantalla de mi ordenador. Internet es uno de los nexos que les une y el lugar que muchos de ellos decidieron utilizar, desde adolescentes, para colgar sus primeros poemas, pensamientos, reseñas o citas preferidas. Tras cuatro o cinco años de búsqueda en los blogs, di con una serie de nombres que con el tiempo fue creciendo. Algunos de ellos se convirtieron en mis amigos, otros en mis links, y otros en algunos de mis autores contemporáneos más respetados. Muchos me gustaban. Muchos merecían ser leídos y publicados y yo quería ayudar. En diciembre de 2010 creé Estaban locos, un Tumblr en el que intentaría publicar a todos esos autores y a los que en adelante conocí, principalmente nacidos entre 1983 y 1993 [...] La versión online de este libro cuenta con más de cien colaboradores de distintos lugares del mundo (Miguel, 2011: 10-11)

Tenian veinte años y estaban locos recoge a veintisiete poetas que "luchan en la calle, en la red y en el papel con la poesía como estandarte" (Miguel, 2011: 10) en un momento histórico de profunda crisis en España que generó (y continúa haciéndolo) un estado de shock neoliberal (Klein, 2012). En consonancia con las ideas de Ángela Martínez Fernández, que analiza esta antología a partir de las citadas teorías de Naomi Klein, en estas páginas se aúnan "la emergencia no solo de nuevas subjetividades, sino también de movimientos sociales y luchas contestatarias que, en algunos casos, llegan hasta el terreno artístico" (Martínez Fernández, 2014: 392). En esta situación de miedo colectivo "el sujeto escribe desde un estado de shock producido por la crisis económica de España (violencia del capitalismo y privatizaciones), de manera que construye voces poéticas que tienen los efectos de ese trauma" (Martínez Fernández, 2014: 396). Reformulando a Ben Clark (2006: 15-16), estos veintisiete jóvenes fueron (fuimos), es cierto, "hijos de la bonanza" que no conocieron ni la hambruna ni las agudas larvas de estridencia, que simplemente intentaron ir viviendo, haciendo caso omiso a los escrúpulos hasta que al fin se

\footnotetext{
20 Antologados: Alberto Acerete, Cristian Alcaraz, Bárbara Butragueño, Laura Casielles, Ernesto Castro, Cristina Fernández Recasens, David Leo García, Berta García Faet, Javier Gato, Álvaro Guijarro, Alberto Guirao, Odile L’Autremonde, Ruth Llana, María M. Bautista, Constantino Molina, Enrique Morales, Raúl E. Narbón, Sara R. Gallardo, Marina Ramón-Borja, Eba Reiro, Judit del Río, Emily Roberts, Laura Rosal, Miguel Rual, María Salvador, Ángel de la Torre y Unai Velasco.
} 
encontraron de bruces, como sucede al leer el poema de Ben Clark, con la manifiesta realidad: ciertamente somos los herederos de todos los despojos. El poeta ibicenco no formó parte del elenco seleccionado por Luna Miguel, aunque poco importa, pues la impronta de esos versos es un resumen muy certero del sentimiento de toda una generación de jóvenes que, de alguna forma, late en el prólogo de esa "locura poemática" (Martínez Fernández, 2014: 413) que es la antología: "en estos días que corren tan difíciles para la juventud, minados por la desconfianza política, la incertidumbre y la indagación, solo la literatura y solo su literatura parecen traer un poco de esperanza a nuestros ojos" (Miguel, 2011: 9-10). Estos poetas hacen bien suya la máxima del Bolaño de Los perros románticos ya en el propio título y cabalgan, si cabe, más allá: "En aquel tiempo yo tenía veinte años / y estaba loco. / Había perdido un país / pero había ganado un sueño" (Bolaño, 2006: 13). Y es este punto, creo, este espacio concreto de la falta, también tras la senda de Ángela Martínez, uno de los nexos principales con respecto a las condiciones materiales en las que se enmarca Tenían veinte años: "Es precisamente esa pérdida de país uno de los sentimientos generalizados que surgen a raíz de la crisis española: la privatización de los servicios públicos hace que los ciudadanos sientan una pérdida de los derechos de asistencia básicos que, a su vez, se suman a las cifras ascendentes de emigración entre la juventud" (Martínez Fernández, 2014: 413).

Tenian veinte años y estaban locos se instala a caballo de una "fiesta de poetas ilusionados, un hogar de poetas sin prejuicios" (Miguel, 2011: 10) y un "manicomio joven, lúcido y lírico" (2011: 12), repleto de quienes "nunca rezan porque saben que están locos. Que estando locos todo es posible. Que aún queda mucho, pero, oye, lo hacen bien. Lo saben hacer. Lo están haciendo. Nunca por un Dios. Sí por la poesía" (2011: 13-14). Es decir, brota de un "puñado de soñadores" (2011: 14) locos (como también explicita el poema de Bolaño) que, pese a no creer en la literatura como una herramienta en pos de la emancipación social, sí consideran firmemente, al menos, que los versos tienen el potencial de devenir bocanada de aire fresco o espacio en el que respirar momentáneamente, "en este mundo de lobos donde los otros tan otros siempre" (Bárbara Butragueño en Miguel, 2011: 34). Esto es, la locura en tanto salvaguarda o "resistencia a los procesos de homogeneización subjetiva" (Martínez Fernández, 2014: 413) que nos permita evitar aquello que el hablante lírico de un poema de Judit del Río anuncia: "Arrancarme la lengua y morderme la oreja como un perro iracundo" (Judit del Río en Miguel, 2011: 142).

Es curioso que Tenían veinte años y estaban locos no contenga un programa estético enarbolado a modo de etiqueta de guerra o solapado en burdas pedanterías, ni defienda ningún cambio concreto de poéticas, sino que, más bien, señale la alternativa generacional mediante la anunciación de una nueva hornada de poetas prolíficos y calientes (Jorge Díaz Martínez en Miguel, 2011: 185). Hay huecos, por supuesto, tal y como la propia Luna Miguel manifiesta en el prólogo (2011: 12), a los que siempre podríamos añadir algunos otros nombres más. Ahora bien, pese a ello, a día de hoy, siete años después de su publicación, son muchos los autores antologados a quienes Tenían veinte años les ha permitido acceder a nuevos espacios de difusión. El boom de la antología, insertada en los cauces publicitarios que fueron abiertos ya por Castellet en los años setenta y que fueron reformulados por Luna Miguel y sus antologados añadiendo a la ecuación las potentes redes sociales que estaban comenzando a tomar fuerza y en las que se desenvolvían muy acertadamente, permitió que muchos de ellos pudieran continuar su propio tránsito en las páginas de La Bella Varsovia (Unai Velasco, Berta García Faet [que ya había 
publicado en la editorial cordobesa Introducción a todo, gracias al premio Pablo García Baena], Cristian Alcaraz [también vía Premio Pablo García Baena], la propia Luna Miguel, etc.) y que otros fueran aupados hacia otras editoriales y otros premios de poesía joven, entre los cuales podemos destacar el Premio Nacional de Poesía Joven Miguel Hernández, que han conseguido los antologados Laura Casielles (2011), Unai Velasco (2013) y Constantino Molina (2016).

Otra similitud con Castellet es el carácter prospectivo de la antología. Tenían veinte años y estaban locos, de igual manera que Nueve novísimos poetas españoles, se pensó y publicó también con anterioridad a la aparición pública de muchos de los nombres incluidos en su nómina: los hay, dice Luna Miguel, “con libros publicados. Los hay con libros por publicar” (2011: 13) y, también, "era 2011, recordarán, y sus voces [...] penetraban como aire fresco, fresquísimo, en nuestras vidas [...] ¿Alguien se acordará de ellos? ¿Alguien volverá a leerlos? ¿Alguno, más tarde, llegaría a publicar su primer, segundo o tercer libro? ¿Alguno, más tarde aún, renegaría de aquellos textos? ¿De aquella antología? ¿De aquella locura que lo caracterizaba? ¿Acaso la echa de menos?" (Miguel, 2011: 9). Ahora bien, hay una importante diferencia: el crítico catalán, recordemos, da por hecho una generación cuando esta todavía se encuentra en pleno proceso de construcción; Luna Miguel, por su parte, no manifiesta aquí ese carácter programático, no define los rasgos de una generación, no pretende dirigir a los jóvenes poetas hacia una establecida práctica de escritura (como ocurrió en buena parte de las antologías de los años ochenta y noventa propugnadas por José Luis García Martín o Luis Antonio de Villena, entre otros) y tampoco subraya la necesidad de un etiquetado dirigido a la parcelación, categorización y comercialización de un determinado tipo de poesía con fines comerciales. Hubo capital simbólico y (en parte) económico en juego, por supuesto; sin embargo, los medios de los que se sirvieron para alcanzarlos fueron muy diferentes a los que hemos analizado en apartados anteriores. Por ello, respondiendo a la pregunta de esta sección: sí, creo que es posible hablar, al menos en determinados aspectos, de un nuevo paradigma antológico que comienza a definir Luna Miguel en 2011 y que veremos a continuación si ha seguido la línea de Tenían veinte años y estaban locos o si, por el contrario, ha vuelto a mirar hacia las turbulentas aguas del etiquetado generacional.

\section{HaCia una CARTOGRAFÍa del CAMPO ACTUAL I: La PRESENCia DE LAS NUEVAS VOCES EN LaS ANTOLOGÍAS DIACRÓNICAS}

Pero lo más difícil es matar a tu padre y seguir llevando flores a su tumba. Rafael Banegas (2011: 16)

Aunque la presencia de autores de los ochenta y los noventa en diversas antologías había comenzado ya en los primeros años del nuevo milenio, es la eclosión de Tenían veinte años y estaban locos, junto a la consecución de premios relevantes y al goteo publicaciones de estos jóvenes en editoriales de diversa importancia (desde sellos independientes hasta Visor o Hiperión), lo que permitió que sus nombres fueran cada vez más habituales en estos compendios. Nos centramos en este apartado en aquellas antologías diacrónicas, esto es, las que han recopilado a autores nacidos en los ochenta y noventa, cuya aparición en el panorama se dio ya en el nuevo milenio (tal y como indican las bases de este monográfico), junto a otros de mayor edad. 
Heterogéneos, editada por David González y Eduardo Boix también en 2011, es una de las primeras antologías en la que se recoge a un sustancial número de poetas nacidos en los ochenta, entremezclados, eso sí, con autores de mayor edad: "una selección generacional de autores, nacidos entre 1970 y 1987 [...] un tremendo elenco de poetas desarrollados en la democracia. Voces fuertes y jóvenes y sedientas" (González y Boix, 2011: contraportada). Estos son: Eduardo Boix, Arturo Méndez Cons, Javier Das, Lluis Pons Mora, Julieta Viñas Arjona, Alberto GarcíaTeresa, Ignacio Escuín, Alejandra Vanessa, Alicia García Nuñez, Carmen Beltrán Falces, Laura Pérez Manzano, Hasier Larretxea, Vanessa Díez Tari, Eduardo Fariña Poveda, Ana Patricia Moya, Pablo López Gargallo, David Refoyo Aguiar, Sofía Castañón, Javier Pascual Ramírez, Antonio Huerta, Ben Clark, Elena Medel, Martín Mosteiro Espina, Almudena Vidorreta, Javi Gato.

Ese mismo año ve la luz Poesía ante la incertidumbre. Antología (Nuevos poetas en español), una propuesta globalizadora y con tintes universalista que pretendía acercar España y América Latina al plantear "una nueva poesía transatlántica como no se veía desde hace un siglo en los tiempos del modernismo" (Pacheco, 2011: 62) a partir de las voces de ocho poetas nacidos entre 1973 y 1982: Jorge Galán (El Salvador), Raquel Lanseros (España), Francisco Ruiz Udiel (Nicaragua), Daniel Rodríguez Moya (España), Ana Wajszczuk (Argentina), Andrea Cote (Colombia), Alí Calderón (México) y Fernando Valverde (España). A este respecto, Fernando Valverde se cuestiona por el lugar de la poesía en las sociedades contemporáneas, marcadas, dice, por la pérdida de las grandes certezas ideológicas (ya analizadas por Lyotard o Jameson), por el descrédito de la política, por la pérdida de la soberanía de los estados y por lo frenético de las actuales formas de vida (Valverde, 2016: 305-306), y acaba por contestar(se), en una suerte de (re)afirmación de las teorías de Luis García Montero a principios de los noventa, lo siguiente: "En aquel momento, teníamos la sensación de que la poesía se encontraba arrinconada, de que habíamos perdido muchos de los vínculos que la habían conectado desde su origen con las personas normales, con los lectores capaces de emocionarse con un poema de forma espontánea, sin la necesidad de ser especialistas o investigadores de la literatura" (Valverde, 2016: 306). Reformula Valverde en esta defensa a la poesía ante la incertidumbre lo que ya firmaran los ocho antologados en el prólogo "Defensa de la poesía" (VVAA, 2011: 7) y que también hemos visto reflejado en los textos de Santiago Espinosa (2016: 315-327)21 y Allen Josephs y Luis David Palacios (2016: 329-335)22. Es aquí, en las líneas de este proemio, donde los poetas tratan de buscar un espacio para la poesía en este mundo en crisis y, de nuevo, siguiendo la estela teórica del García Montero de la "poesía para los seres normales" (1993b) y del Ángel González de la poesía entendida como claridad y significación potenciada (2003), proponen un supuesto viaje a la esencia (VVAA, 2011), que es, en resumen, una actualización en pleno siglo XXI de la eterna diatriba entre realismo y vanguardia que ha atravesado la poesía española contemporánea. Por supuesto, la crítica aquí repite los viejos moldes y adquiere una doble direccionalidad: por una

\footnotetext{
${ }^{21}$ Espinosa habla de "cinco mandamientos o pecados originarios" (2016: 318): "Estos poetas creen en una respuesta emocional frente a la incertidumbre que vivimos", "Quieren comunicar o sacudir al lector, creen que en la poesía hay una comunidad de lectura", "Quieren relacionarse con la tradición desde el diálogo", "Creen que puede haber una poesía del aquí y del ahora" y "creen que en la poesía existe una posibilidad de integrar los disperso" (Espinosa, 2016: 318-321).

22 Josephs y Palacios afirman: "La emotividad de un texto no es un fin estable y cerrado, sino un movimiento gradual, un transcurso en estrecha unión con el sujeto. Nos hace falta una semiótica de la emoción. Un acercamiento a la poesía que nos permita considerar lo emocional como efecto inmediato del sentido" (2016: 335).
} 
parte, una defensa de los presupuestos del figurativismo y del realismo ("creemos en una poesía que además comunique, que diga algo, que porte sentido"[VVAA, 2011: 8]); por otra, un ataque frontal al experimentalismo y la vanguardia ("Ante tanta incertidumbre, para nuestra sorpresa, una gran parte de los nuevos poetas en español se han adscrito a una tendencia tan experimental como oscura" [VVAA, 2011: 8] y "hoy la poesía está considerada como un género difícil que solo leen los poetas, porque solo parecen entenderse entre ellos como los habitantes de ínsulas extrañas [2011: 9]).

Así pues, estamos ante una antología que (re)actualiza y, en algunos casos, repite, los principios en los que se fundamentó buena parte de la lírica figurativa desde los años ochenta en España. Pero no solo eso, sino que también retorna a buena parte de los lugares comunes de la crítica de los años veinte y treinta ("Queremos mostrar nuestra desolación ante esa dinámica que nos parece destructiva para la poesía porque conduce, de manera inevitable, a su deshumanización" [VVAA, 2011: 9]) y que tuvieron, de alguna forma, continuidad a lo largo de los años cincuenta y sesenta ("En el fondo, aquel texto pretendía defender la poesía como comunicación" (Valverde, 2016: 307). El objetivo no es, por lo tanto, el tan recurrido matar al padre, sino sumarse a su estela para no "oponerse a quienes tanto han trabajado para que la poesía se entienda, se humanice, se aproxime a la gente corriente" (VVAA, 2011: 8), siempre, por supuesto, tras la senda orteguiana. Esto es, acercar sus posturas a una tradición que ellos mismos explicitan: Ángel González, Jaime Gil de Biedma, Gonzalo Rojas, Claribel Alegría, José Hierro, Luis García Montero, Benjamín Prado (y los poetas de la conocida poesía de la experiencia), Juan Manuel Roca, Marco Antonio Campos, Jorge Boccanera, José Emilio Pacheco, Mario Benedetti, Gioconda Belli, Óscar Hahn, Omar Lara, Waldo Leyva o Piedad Bonett (VVAA, 2011: 9), deudores, según indican también en el texto, de Rafael Alberti, Antonio Machado, César Vallejo (habría que preguntarse qué Vallejo, en este caso), el primer Octavio Paz, Pablo Neruda, Miguel Hernández, Federico García Lorca (también valdría la misma pregunta que sobre Vallejo), Luis Cernuda (de nuevo, podemos repetir la misma cuestión), etc. (VVAA 2011: 9).

Tras la senda de Remedios Sánchez, podemos considerar esta poesía ante la incertidumbre como una nueva corriente poética, homogénea y ligada con la realidad, conformada por escritores de seis países, en igualdad de condiciones y con un ideario común, una muestra altamente significativa del porvenir del verso escrito en español y marcada por alejarse de los hermetismos y florituras y por un acercamiento a la transparencia, al vuelo de la imaginación y al apego a la vida (Sánchez García, 2012: 115). Ahora bien, considero que deberíamos matizar estas palabras. Por una parte, es cierto que la novedad de la propuesta radica en una suerte de globalización del hecho poético a partir de la "unión de varios caminos" (Espinosa, 2016: 317) peninsulares y latinoamericanos. Por otra, no es tan cierto que podamos hablar de una nueva corriente poética, sino más bien de una inercia de los presupuestos experienciales, que renueva sus nombres y caras visibles, pero no su estética. Si saltamos por encima de este importante matiz, correríamos de nuevo el riesgo de equiparar lo joven con lo novedoso, como tantas y tantas veces ha ocurrido en la crítica española. Ahora bien, sí es cierto que Poesía ante la incertidumbre es una muestra altamente significativa de lo porvenir. Al menos, así lo indica, primero, la publicación de la antología en uno de los más relevantes sellos editoriales en España (Visor); segundo, la atención editorial que demuestran las posteriores ediciones que han aparecido en Argentina (El Suri Porfiado), Chile (Trilce), Perú (Mesa Redonda), Bolivia (Editorial La 
Mancha), Ecuador (El Ángel Editor) e Italia (Raffaeili Editori, traducida por Emilio Coco) tal y como indica Fernando Valverde (2016: 309); y, tercero, los recientes acercamientos de algunos de los más relevantes investigadores y críticos, muchos de los cuales han sido citados en estas páginas y que han reunido buena parte de sus análisis en el amplio e importante volumen Palabra beredada en el tiempo. Tendencias y estéticas en la poesía española contemporánea (1980-2015), coordinado por Remedios Sánchez García (2016).

Con la misma voluntad universalista, con el mismo objetivo de defender la poesía frente a una supuesta deshumanización (que es anunciada en diversos acercamientos) 23 y tras la misma senda de aglutinar bajo un mismo marbete (de nuevo, el etiquetado del que hablábamos varias páginas atrás utilizando las reflexiones de López Merino y Méndez Rubio, y lo publicitario, tras la senda de Talens) a diferentes prácticas poéticas surgidas en diferentes espacios más allá de las fronteras españolas e, incluso, más allá de las fronteras lingüísticas, nació Humanismo solidario. Poesía y compromiso en la sociedad contemporánea (Sánchez García y Bianchi, 2014). La antología recogió a medio centenar de poetas españoles, latinoamericanos, magrebíes, subsaharianos y de Oriente Próximo nacidos entre los años cincuenta y ochenta (entre los cuales, también se encuentra Fernando Valverde) que venían reivindicando "una lírica solidaria y universal [...] desde la conciencia imperiosa y compartida de volver la mirada al ser humano sin imposturas, de un deber real, un comportamiento ético y un posicionamiento reflexivo como eje transmisor y perseverador de la fraternidad entre los individuos, constantemente manipulada y cercenada en estos tiempos de miseria moral" (Morales Lomas, 2016: 384). En este sentido, sobre las líneas de fuerza del Humanismo Solidario ha hablado Marina Bianchi en unas amplias reflexiones que, sin embargo, no acaban de profundizar en los argumentos apuntados, lo cual, por otra parte, dificulta por su propia generalización una crítica de sus premisas que no derive en algún momento en alguna manifiesta contradicción. De ahí, quizás, su propia fuerza aglutinadora:

El Humanismo Solidario reúne a escritores procedentes de distintas corrientes, ideologías y países, que comparten el objetivo de reafirmar la capacidad del verso de conjugar la percepción personal y la colectiva, hablando de lo universal desde lo particular, de problemas y malestares compartidos desde la sensibilidad y vivencia de cada uno. En otras palabras, ofrecen cavilaciones sobre el momento y la situación que vivimos, para que el lector elija su estado de ánimo, su actitud y los valores por los que se quiere luchar, desde la cultura, desde la libertad de la palabra y desde la libertad de la poesía, derechos universales que las instituciones defienden solo de forma aparente (Bianchi, 2016: 436-437)

Sin voluntad de profundizar en el tema, primero porque su amplitud bien necesitaría un espacio que aquí no poseemos y, segundo, porque no afecta a una extensa nómina de escritores nacidos a partir de 1980 (como indica este monográfico), sí queremos dejar constancia, al igual que ocurría con Poesía ante la incertidumbre, que esta corriente (más vinculada con una filosofía universalista que con lo poético en sí mismo), ha sido también muy tenida en cuenta por la crítica, tal y como podemos comprobar en la bibliografía citada. De la misma forma que en el caso anterior, nos encontramos muy probablemente ante una etiqueta que puede marcar las derivas del

23 Hablamos de Sánchez García y Bianchi (2014), de Francisco Morales Lomas (2016: 381-392), de Albert Torés (2016: 393-402), de Manuel Gahete Jurado (2016: 403-414) y de José Sarria Cuevas (2016: 415-426) y de Bianchi (2016: 427-438). 
campo poético en los próximos años, tanto por los apoyos recibidos (hasta 600 intelectuales han firmado su manifiesto), como por la difusión que le permite Visor (de nuevo, Visor) y por el auge de análisis críticos. Por el momento, únicamente tenemos en nuestras manos la posibilidad de lanzar predicciones que solo el tiempo nos dirá si son o no acertadas. Sea como sea, las bases están ya creadas y los medios dispuestos para su transmisión y su defensa.

En cierta medida, ambas propuestas recuerdan y dialogan con las derivas poéticas acaecidas en los años ochenta en España tras la eclosión de la otra sentimentalidad granadina y el posterior apogeo de la poesía de la experiencia, en lo que respecta, al menos, al supuesto acercamiento a lo humano. Frente a este socorrido argumento, de base orteguiana pero utilizado en la inmensa mayoría de ocasiones como un arma arrojadiza sin demasiada reflexión al respecto, cabría cuestionarse, sin ir más lejos, qué es un arte humanizado o incluso si puede existir una poesía completamente deshumanizada (es decir, sin rasgos de lo humano) y, también, tratar de responder por qué siempre la crítica poética en España ha relacionado lo humano con el realismo y lo deshumanizado con cualquier otra forma de escritura. En la misma línea, podemos recordar las citadas reflexiones de Jiménez Heffernan, en las que defendía que la poesía española de los ochenta representa una amortiguación edénica del arte, cuya autenticidad se busca en máscaras exóticas y horizontes elegantemente realistas que habitan siempre bajo el signo de un blando y amable neohumanismo (Jiménez Heffernan, 2004: 426). No deja de resultar paradigmático el carácter cíclico del campo poético español, pues tales palabras pueden ser perfectamente extrapolables a la actualidad, si atendemos, por ejemplo, a Poesía ante la incertidumbre y a Humanismo solidario. No pensemos tales compendios como dos revolucionarios acercamientos que han pretendido establecer nexos de cariz internacionalista entre los creadores a ambos lados del Atlántico, como sí propusieron, por ejemplo, buena parte de los creadores de los años treinta con los Congresos de Escritores Antifascistas o con el diálogo surgido en el exilio tras la Guerra Civil, pues andaremos errados. Más bien, debemos comprenderlos en el actual contexto de libre mercado neoliberal como una herramienta publicitaria paralela a la globalización socio-política y económica que se fundamenta en el auge del etiquetado como medio para la acumulación de capital simbólico y económico. Estas parcelas del campo poético, por lo tanto, han aprendido el funcionamiento de los cauces del capitalismo y los han transitado a partir de la práctica antológica, lo que ha permitido poner a su alcance grandes medios de difusión y de mercantilización de ideas y productos, lo cual, por otra parte, no debe extrañarnos lo más mínimo, pues el carácter totalizador de las estructuras del capital (de ese mundo interior del capital del que hablara Sloterdijk [2007] ${ }^{24}$ o de la desaparición del exterior de Antonio Méndez Rubio $[2012]^{25}$ ) acaba por alcanzar todas las esferas de la vida en común (públicas y privadas). El campo poético, aunque pequeño reducto de unos pocos, no puede escapar de ello pues, al fin y al cabo, forma parte de esa amalgama de tintes totalizadores. Quizás, podríamos pensar, haya podido

\footnotetext{
24 Dice Sloterdijk: "Dentro del espacio interior capitalista de mundo hay que partir de la primacía de los hechos económicos; pero estos hechos tienen siempre, por sí mismos, un carácter político-mundial, más exactamente: geopolítico, porque el Gran Invernadero no puede ser administrado con éxito sin aseguramiento de recursos y management de la piel exterior" (2007: 295)

25 Dice Méndez Rubio: "Por desaparición del exterior habría entonces que entender no un exterior finalmente eliminado o superado sino convertido en una amenaza ambiental o espectral, en un lugar de violencia y muerte cada vez más invisible por ser cada vez más inminente" (2012: 15).
} 
mantenerse más al margen que otros espacios socialmente más amplios (o masivos, incluso) de la cultura (narrativa, cine o música, por ejemplo), sin embargo, sería demasiado idealista imaginar que las redes del mercado global vayan a mantenerse completamente alejadas: valga, como ejemplo paralelo, la actual best-sellerización de la poesía, de la que han participado autores como Marwan, Loreto Sesma, Elvira Sastre o Defreds, entre muchos otros y otras, así como diversos sellos editoriales de enorme calado como Mueve tu Lengua (anteriormente, Frida Ediciones), Lapsus Calami, Planeta, etc., o, más recientemente, Visor (al publicar La soledad de un cuerpo acostumbrado a la herida, de Elvira Sastre).

Volviendo al recorrido antológico, otro compendio que también ha profundizado en la unión de las dos orillas del atlántico es El canon abierto. Última poesía en español (1970-1985) (Sánchez García y Geist, 2015). Publicada en Visor, la selección de los poetas antologados (trece de ellos españoles: once nacidos en los setenta y dos, Elena Medel y Fernando Valverde, en los ochenta) se elaboró a partir de una consulta entre más de 200 críticos de diversos países. En el prólogo se explicita su voluntad de mostrar la realidad literaria de los diversos espacios de habla hispana, "con sus estéticas dominantes, las del centro y las periféricas, primarias y secundarias" (Sánchez García, 2015: 75), sin embargo, el propio sistema de selección favorece, por otra parte, que la inmensa mayoría de antologados pertenezcan a la mayoritaria estética figurativa que todavía hoy ocupa el centro del campo poético. Si, como hemos visto por extenso, el relato poético de la España contemporánea se ha sustentado en una defensa constante de las poéticas realistas y en un sistemático ataque a las prácticas que han dialogado con las tradiciones vanguardistas $\mathrm{o}$, directamente, no realistas, así como en la aparición constante de determinados nombres en las principales antologías (entendidas, como lo hemos hecho hasta este punto, como parte fundamental en los procesos de canonización y en la construcción del relato de la historia literaria), no es de extrañar que fuera Fernando Valverde el poeta con mayor número de votos o que Elena Medel ocupe la tercera plaza entre los nacidos en España.

Es cierto que, siguiendo a Luis Bagué y Alberto Santamaría, la poesía actual exige una "mirada laberíntica" que supere las polaridades entre "experienciales y metafísicos, figurativos y abstractos, poetas del diálogo y poetas del fragmento o defensores de la lírica como género literario frente a partidarios del carácter inefable de la expresión poética" (2013: 11-12) sobre las que se construyó el campo poético desde finales de los años ochenta y que el propio Luis Bagué trató de superar en Quien lo probó lo sabe 36 poetas para el tercer milenio (2012), con un amplio corpus de poetas de diferentes edades y generaciones que escriben "desde el lado imprevisto del mundo y del lenguaje" (2012: 15): de Jorge Riechmann a Elena Medel, pasando por Antonio Méndez Rubio, Roger Wolfe, Luis Muñoz, Ada Salas, Erika Martínez, Ana Gorría, Juan Carlos Abril o Enrique Falcón, etc. También es verdad que antologías como Deshabitados, de Juan Carlos Abril (2008), trataron de abrir nuevas sendas en el campo poético a partir de la constatación de la existencia de una tercera vía alejada del naturalismo y lo ensimismado donde lo fragmentario adquiere más relevancia, dando la sensación de una práctica poética hecha de retales o esquirlas (2008: 29), en correlación con la sensación de falta que atraviesa al sujeto contemporáneo en las sociedades actuales (ya teorizada por Lacan o Foucault). Abril lo hace, de nuevo, con una amplia selección de poetas nacidos entre los setenta y los ochenta, como Elena Medel (de nuevo), Fruela Fernández, Juan Andrés García Román, Yolanda Castaño o Alberto Santamaría, entre muchos otros. Ahora bien, son estas dos calas en la práctica antológica poco habituales, apenas dos islas 
en un inmenso archipiélago que ha premiado determinadas prácticas de escritura desde hace décadas. El carácter (más) aglutinador y panorámico de Luis Bagué y Juan Carlos Abril es, sin llegar a ofrecer una panorámica de todas las estéticas que actualmente está desarrollándose, una suerte de susurro entre el inmenso ruido de la práctica antológica mayoritaria de la España contemporánea.

Otra interesante cala es Disidentes. Antología de poetas críticos españoles (1990-2014), en la que Alberto García-Teresa ha recopilado ochenta y un nombres vinculados a la poesía de la conciencia crítica, en un intento de complementar su imprescindible estudio de 2013 Poesía de la conciencia crítica (1987-2011) y de reclamar la existencia e importancia de esta vertiente creativa en España. En sus páginas, se dan cita poetas nacidos en los ochenta (David Refoyo, Antonio Rómar, Paz Cornejo, Sara Herrera Peralta y Sergio C. Fanjul) y los noventa (Enrique Martín Corrales) cuyas voces, de manera central, constante o bien en amplios tramos de su trayectoria, y no solo de forma puntual o circunstancial, ni reservada a declaraciones y manifiestos, "han hecho en su práctica poética del verso [...] una expresión de disidencia y de antagonismo; una crítica a la estructura socioeconómica actual, a su ideología y a los valores que la sustentan" (García-Teresa, 2015: 9). Todo ello, desde una diversidad de abordajes y desde una multiplicidad de registros que, lejos de anclarse en una opción estética determinada, dan pie a diferentes formas de enunciación poética, de toma de la palabra y de modulación de la misma, que abarcan la dicción clara y el registro narrativo, pero también la expresión surrealista y el ritmo disruptivo, pasando por el collage, la captura de hablas populares, lo elíptico o el carácter épico. No nos encontramos, por lo tanto, ante una antología programática (como tampoco lo fueron las directamente relacionadas Feroces u Once poetas críticos en la poesía española reciente), pues no es su objetivo hacer generación en tales páginas, sino más bien ofrecer una fotografía de lo que ha supuesto la poesía de la conciencia crítica en las últimas décadas, esto es, "un repertorio completo y exhaustivo de poetas críticos españoles en lengua castellana contemporáneos; un volumen que sea reflejo de esa pluralidad y riqueza de enfoques, que pueda responder tanto al presente como al futuro, y que revele las numerosas voces que se levantan desde el conflicto socioeconómico, político y ecológico que nos atraviesa” (García-Teresa, 2015: 10).

Así pues, la presencia en los repertorios antológicos de los más jóvenes poetas del panorama es cartografiable en muy numerosas y variadas antologías publicadas en los últimos años. Como vemos, en términos generales la pauta ha sido la de una continuación inercial de los presupuestos experiencialistas y meditativos que coparon el centro del campo poético desde finales de los años ochenta, con algunas vetas con mayor amplitud de miras, que, sin embargo, no han copado en ningún caso (por voluntad propia o ajena; propia y ajena, quizás) los cauces de difusión mayoritarios ni las plataformas críticas de más amplio calado. Como ha venido ocurriendo en las últimas décadas, han sido los repertorios que han reclamado una poética figurativa los que han gozado de un mayor alcance, de un mejor posicionamiento editorial y de una considerable atención en diversos medios (revistas académicas, revistas culturales o literarias, suplementos, etc.). El carácter programático que marcó el devenir antológico de los años noventa (con José Luis García Martín o Luis Antonio de Villena como principales valedores), ha ido dejando paso a una nueva poética de la antología que no focaliza tanto en la construcción de generaciones (como venía sucediendo desde Castellet), aunque sí persiga desde sus posiciones de poder la canonización de determinadas tendencias. En los casos vistos en este apartado, nos 
encontramos ante unas antologías que parten de la inclusión de nombres y tendencias ya instaurados en el panorama, para acabar incluyendo en sus nóminas a poetas más jóvenes, aunque, en la gran mayoría de ocasiones, ya bastante reconocidos. En pocas ocasiones (como sucede en las compilaciones de Luis Bagué y Juan Carlos Abril) se da un (no demasiado) arriesgado juego en el siempre afilado filo de lo prospectivo que, en ningún caso, se asimila a la marcada apuesta de futuro que de alguna forma inició Castellet con Nueve novísimos y que han transitado otros antólogos en las últimas décadas, pues son pocos los nombres recopilados que no cuenten con una más que aceptable y consolidada carrera por las sendas de lo poético. De todo ello podemos extraer que algo ha cambiado y que, a su vez, algo se ha mantenido. Ahora bien, ¿qué sucede con aquellos repertorios cuyos antologados pertenecen por completo a esa última hornada de nacidos ya a partir de los años ochenta?

\title{
7. HACIA UNA CARTOGRAFÍA DEL CAMPO ACTUAL II: LA PRESENCIA DE LAS NUEVAS VOCES EN LAS ANTOLOGÍAS SINCRÓNICAS
}

\author{
Pobre de aquel que mire \\ y vea claro \\ Claudio Rodríguez (1985: 62)
}

Si en el apartado anterior nos centrábamos en las antologías que recopilaron a autores nacidos en los ochenta y noventa, cuya aparición en el panorama se dio ya en el nuevo milenio (tal y como indican las bases de este monográfico) junto a otros de mayor edad, queremos, en esta séptima sección, centrarnos en los repertorios sincrónicos, es decir, aquellos que han recogido la obra de poetas nacidos en los ochenta y noventa (hayan sido estos editados o no por autores también jóvenes).

En este sentido, en los últimos años, han visto la luz al menos cuatro repertorios antológicos que, siguiendo la estela de Luna Miguel en Tenían veinte años y estaban locos, han recogido composiciones de una sustancial y variada muestra de los más jóvenes poetas del panorama. En 2014, la propia Luna Miguel vuelve a ejercer de antóloga en La poesía posnoventista española en 15 voces, publicada en línea (Miguel, 2014), que aglutina composiciones de autores nacidos entre 1990 (Arturo Sánchez) y 1997 (Rosa Berbel). En 2016, Miguel Floriano y Antonio Rivero Machina recogen a veintiocho poetas nacidos entre 1980 (Sergio C. Fanjul) y 1997 (Óscar Díaz) en Nacer en otro tiempo. Antología de la joven poesía española, bajo el sello de la prestigiosa editorial sevillana Renacimiento (Floriano y Rivero Machina, 2016). Ese mismo año, el reconocido crítico y poeta abulense José Luis Morante coordinó Re-Generación: antología de poesía española 2000-2015 (Morante, 2016), publicada en Valparaíso Ediciones, que recoge obras de veinticuatro poetas nacidos entre 1980 (Fernando Valverde) y 1993 (Xaime Martínez). Y, también en 2016 Rafael-José Díaz (2016) publica en línea Identikit. Muestra de poesía española reciente, compuesta por obras de doce poetas nacidos entre 1981 (Javier Vela) y 1992 (Yeray Barroso). Finalmente, a partir de la revista Kokoro es publicada en 2017 Voz vértebra. Antología de poesía futura (VVAA, 2017). Ahora bien, antes de detenernos en estos compendios, conviene que actualicemos algunas consideraciones anteriormente comentadas. 
Pensar las antologías últimas supone un ejercicio que nos retrotrae de alguna forma a buena parte de los compendios surgidos a partir de Nueve novísimos poetas españoles, en tanto nos encontramos ante repertorios que persiguen abiertamente recopilar y reclamar la práctica poética ejercida por los más jóvenes autores del campo poético. Existen, por supuesto, poetas lo suficientemente asentados y reconocidos que nos permiten afirmar la futura relevancia de sus propuestas en los procesos de canonización que comenzaron a gestarse en los últimos años y que, sin duda, continuarán en las siguientes décadas: Ben Clark, Fernando Valverde, Elena Medel, etc. Sin embargo, algunas inclusiones son apuestas más o menos arriesgadas de los antólogos. No es esta una novedad, sino un hecho rastreable en todo repertorio antológico que haya perseguido reclamar la emergencia de las más jóvenes y noveles voces: ¿acaso no fue menos arriesgado para Luis Antonio de Villena en 1986, cuando publicó Postnovísimos, antologar a Luis García Montero o a Felipe Benítez Reyes que a José Gutiérrez o a Rafael Rosado?, ¿acaso no sabía José Luis García Martín en 1999 que Benjamín Prado, Vicente Gallego o Luis Muñoz eran apuestas mucho más seguras que Pelayo Fueyo, Antonio Manilla o Javier Almuzara? En este sentido, la falta de objetividad es más bien una de las características de la crítica sobre la poesía joven, puesto que "brota de una lectura concreta con su historicidad, su parcialidad y, muy a menudo, también sus intereses de clase y personales, no siempre visibles a primera vista" (López Merino, 2008: 31). Ello, por supuesto, no está reñido con otros detalles tenidos en cuenta en páginas anteriores: la voluntad de reclamar la emergencia de poéticas grupales concretas, el objetivo de entrar en el juego de fuerzas de los procesos de canonización, el egocéntrico sentimiento de ser el antólogo que editó tal o cual compendio e incluyó en él con buen tino a tal o cual poeta (al estilo castelletiano, quizás), la instauración de una etiqueta que abra nuevos cauces a lo publicitario, etc. Y, por supuesto, quizás inconscientemente, el reclamo (de nuevo) de una aceleración (Virilio, 1999) y un presentismo (Hartog, 2007)) acuciantes, que dificultan la atención sobre la ingente maraña de obras publicadas año tras año, a menos que recurramos a las selecciones que determinados expertos en el tema nos presentan. Lo antológico, por lo tanto, se estructura como un problemático nódulo en el que se entrecruzan las mayores tentaciones totalitarias con el carácter más democrático (Ruiz Casanova, 2007: 162). Atender a ello y dejar constancia de lo que está sucediendo se torna así una necesidad de la crítica, entendida, con Foucault, como la herramienta para no ser engañados o, al menos, para no ser engañados de esa forma y a ese precio (2006: 8). Así comprendida, la labor del crítico es la de dejar constancia de lo que (no) se vio (como rezaba una citada afirmación de Méndez Rubio sobre la función de la poesía en las contemporáneas sociedades de la desaparición [2004b: 36]), para evitar que tales discursos no sean ignorados en el momento de su nacimiento hasta devenir, años después, en fuentes primarias cuya estructura ideológica y política de partida no se cuestiona al ser tomadas como datos supuestamente objetivos (Talens, 1989: 39). Y, también, para que no debamos repetir dentro de diez o veinte años las palabras de López Merino sobre la poesía escrita en España tras la muerte de Franco: "Sospechamos que lo único que conocemos es la versión de los hechos que la crítica más influyente fue forjando o modelando a cada momento y la que hoy, aprobada por la repetición, ha quedado configurada como histórica [...] es cierto que el canon cambia, pero también lo es que las mentiras presentes sólo serán reemplazadas o desplazadas por mentiras —o a lo sumo medias verdades - futuras." (2008: 9). Ello nace de la certeza de que el fenómeno de las antologías es un efectivo instrumento de poder que parece proliferar sin remedio (Méndez Rubio, 
2004b: 116), cuya carga ideológica y cuya capacidad de modelización de la historia literaria y de los procesos de canonización hace necesaria una profunda reflexión.

Podemos comenzar este último repaso a la más reciente práctica antológica sobre la más reciente poesía escrita por los más jóvenes autores con el compendio de Luna Miguel La poesía posnoventista española en 15 voces, de 201426. El término posnoventista, que a los asiduos al campo poético español de las últimas décadas les debe recordar inevitablemente a los postnovísimos de Luis Antonio de Villena, es tomado por Luna Miguel del grupo de poetas que cambió la concepción del género en la Argentina de los años noventa, gracias a la conjunción de un espíritu lúdico y de "esas ganas de conocer lo que se había en el mundo, esas ansias por crear editoriales pequeñas de libros baratos que llegaran al público, etcétera" (2014: 2). La apuesta de Luna Miguel es a todas luces arriesgada, ya que recoge composiciones de autores que en algunos casos, como ella misma afirma, tienen libros escritos (en editoriales pequeñas, en webs o en revistas) y, en otros, por escribir, aunque no parecen frustrados por que su publicación no vaya a ser inminente (2014: 3). Es a todas luces una antología de claros tintes prospectivos, que retrata, por supuesto, el más reciente panorama poético, sí, pero siempre con la vista dirigida hacia un horizonte que tan solo el paso del tiempo nos dirá si es lo que parece o es únicamente mera ilusión y simulacro. Así, el compendio nace por voluntad de actualización de la relevante antología Tenían veinte años y estaban locos pues, señala, que en apenas cuatro años desde que la idea de este libro comenzara a gestarse todo ha cambiado mucho, y muy rápido (2014: 2):

Si los autores más jóvenes de la antología en papel habían nacido en 1992, ahora solo hay que mirar un poco la blogosfera, los debates literarios en Facebook y Twitter e incluso algunas revistas para comprobar que los autores de 1990 son cada vez más numerosos, e incluso que sus nombres, a pesar de ser la mayoría poetas inéditos, han llegado a ser bastante influyentes, pues no solo se limitan a escribir sus cositas y compartirlas en la red, sino que compran y leen libros tanto clásicos como de sus contemporáneos, escriben artículos en medios culturales online, comparten lo que les gusta, agitan el género y confían ciegamente en él (Miguel, 2014: 2)

Describe Luna Miguel un universo al que nos hemos tenido que acostumbrar más rápido de lo esperado. Los conflictos, las luchas por las premisas, los juegos de poder y los procesos de canonización en los que estos poetas han tomado la palabra (aunque sea con los tan necesarios susurros de la juventud), son muy similares a los que hemos vivido en las últimas décadas, con la sutil e importante diferencia de que ahora suceden (en su mayor parte) en el espacio de la red global. Por el momento, el objetivo de estos poetas no es el de "ser una joven promesa de tal o cual editorial grande" ni el de pelearse "por salir reseñados en El Cultural (posiblemente ni lean El Cultural", esto es, no desean "agrandar la caspa de ahí arriba" (2014: 3). Y digo por el momento porque en estas páginas es todo inestabilidad y presentismo: poco o nada sabemos de qué les deparará el futuro. Ahora bien, no cabe duda de que su inclusión en un compendio firmado por Luna Miguel bien puede ayudar a un mejor posicionamiento: al fin y al cabo, recordemos, tras la publicación de Tenian veinte años y estaban locos no fueron pocos quienes consiguieron algunos de

\footnotetext{
26 Antologados: Arturo Sánchez, Ruth Llana, Ángel de la Torre, Emily Roberts, Cristian Piné, Sara Torres, Miguel Rual, Annie Costello, Roger Vilanova Jou, Yasmín C. Moreno, Patricia Úbeda Sánchez, Marcos Ortiz Andrino, Belén Benito, Sandra Martínez y Rosa Berbel
} 
los más relevantes galardones poéticos de la España contemporánea (al menos, en lo que a poesía joven se refiere).

Ahora bien, pese a esa aparente voluntad de distanciamiento con respecto a la práctica poética anterior, es significativo que Luna Miguel recurra al ya demasiado transitado recurso del etiquetado, que no habíamos detectado con demasiada profusión en las antologías más recientes (salvo en Humanismo solidario o en Poetas ante la incertidumbre). Dice la antóloga, en un claro bautismo generacional: "Los quince autores que he escogido para hacer una aproximación al postnoventismo español me parecen muy significativos" (2014: 2-3). Y, a continuación, señala algunos rasgos extratextuales comunes que los unen: "A todos los he conocido a través de internet, casi todos han publicado en Estaban locos y otras antologías digitales, casi todos tienen blogs, tumblrs, twitters, instagrams y vidas activas en todas estas redes" (2014: 3). Es cierto que no es esta una caracterización al uso, es decir, vinculada con la recuperación de una(s) determinada(s) tradición(en), con la cercanía a una determinada ideología política y poética o con el rechazo a otras tantas, con la puesta en práctica de determinados rasgos, temáticas o formas, etc. No puede serlo en una antología tan prospectiva como panorámica, es decir, tan optimista como precaria (por la escasez de textos de sus antologados y por el casi inexistente margen temporal), que recoge desde el afán testimonial de Emily Roberts, con ese gesto melancólico de retorno a la infancia que se torna, en muchas ocasiones, una daga que horada los recuerdos y transita la experiencia ("Saludamos al parlamento escocés / descalzas y con las manos bien abiertas, / con los pulmones en los bolsillos, / cuando tallamos nuestros nombres en la lengua materna" [2014: 19]) hasta la sintaxis fragmentadas de tintes postistas de Cristian Piné, en la que se aprecia un amplio trabajo formal que apela con constancia a las aliteraciones ("su surros y de ver tigo tan solo / vi viendo y por si es cosa evidenciar / los susurros el vértigo la vida" [2014: 22]), pasando por el verso contenido y certero de Yasmín C. Moreno ("La enfermedad literaria me corroe. / Llegar a hacer un fósil de mí misma" [2014: 46]), por el torrencial y extenso de Miguel Rual ("Jamás dijeron una palabra solo por mantener las apariencias / y ser considerados mártires de su propia violencia” (2014: 29]) o por los poemas en prosa de Sara Torres (2014: 24-25). Estamos ante un mosaico de prácticas poéticas con voluntad abarcadora en el que, sin embargo, echamos a faltar, como ya sucedía en Tenían veinte años y estaban locos, algunas de las voces más crí(p)ticas del campo poético que, como ha venido siendo habitual, no tienen cabida más allá de los compendios elaborados por los propios poetas y críticos afines a tales sendas creativas (como ocurría, por ejemplo, en el caso de Disidentes con Enrique Martín Corrales). El ejercicio de presentismo de Luna Miguel en esta antología, surgida como continuación de Tenían veinte años y estaban locos, es, por una parte, una suerte de intento programático de recopilación de los nacidos en los noventa (como si el mero hecho de haber nacido en esa década marcara diferencias sustanciales con los nacidos en los ochenta o los setenta) y, por otra, una cartografía del estado actual de la más joven poesía. Ambos aspectos, reunidos en torno a una publicación en red (cabría preguntarse por qué, siendo Luna Miguel quien es en el campo poético, ninguna editorial se ha lanzado a publicar o elaborar un proyecto como este: una cosa, parece ser, es recoger a quienes tienen ya un recorrido y otra muy distinta y mucho más arriesgada a quienes "aún se les nota la timidez y la inocencia" [2014: 3]) son, de alguna forma, un primer paso para tratar de delinear los nuevos mapas de la poesía por venir y, por lo tanto, para participar (a partir de la difusión que permite la red global y de la relevancia de Luna Miguel como crítica y antóloga) en 
los procesos de canonización, a partir de un uso plenamente consciente de etiquetado: no entendido, eso sí, como una marca imborrable, sino como una propuesta o como un cebo que espera ser mordido. El éxito o no de lo postnoventista (difícilmente relacionable aquí con las leyes del mercado, al menos por el momento, por la gratuidad de la publicación) solo dependerá (y Luna Miguel es bien consciente de ello, como creo que lo son también buena parte de los antologados) de la futura aceptación por parte de los críticos y de los análisis y estudios que ellos realicen (por lo pronto, silencio a este respecto).

En 2016, la poesía escrita por los poetas nacidos a partir del ochenta, que había comenzado a tener su visibilidad pública en 2002, tal y como ya hemos comentado, ocupa ya una amplia parcela del campo poético. Ante la emergencia de decenas de nuevas voces, brotó la necesidad de trazar una guía entre la maraña de nombres. A esta tarea, que comenzaba a ser reclamada por el público lector, se lanzaron los antólogos antes citados, para ofrecernos un callejero, más o menos (in)completo, de la más reciente ciudad de los poetas.

Si tuviéramos que señalar las líneas comunes que emergen de Re-Generación ${ }^{27}$, Nacer en otro tiempo28 e Identikit29, y que incluso los antólogos explicitan, deberíamos destacar, al menos, tres elementos. Primero, la disposición "para un primer recuento generacional sobre la lírica emergente" (Morante, 2016: 11) o, en otras palabras, "el objetivo de bosquejar un mapa que aproxime cabalmente al lector a nuestra joven poesía" (Floriano y Rivero Machina, 2016: 225) con el convencimiento de que toda antología ofrece un "catálogo incompleto" (Díaz, 2016: 12). Segundo, manifestar (como también hiciera Luna Miguel), la importancia de "la democratización de internet" (Valverde, en Floriano y Rivero Machina: 2016: 10)30 y "la profunda conexión entre el momento poético más reciente y la crecida digital” (Morante, 2016: 11), hasta el punto de que Identikit ha sido únicamente publicada en línea (como ocurrió con La poesía posnoventista española en 15 voces). Y, tercero, señalar la pluralidad de estéticas y estilos existente, que, lejos de haber creado un panorama conflictivo, nos ubica "ante una convivencia sosegada de idearios, un espacio en marcha que siembra en cada taller la esperanza del fruto singular" (Morante, 2016: 12), esto es, una "diáspora de autores activos, caótica de tan vasta" (Floriano y Rivero Machina, 2016: 225), una "insobornable pluralidad" (Díaz, 2016: 11), una "polifonía generacional" en la que "se han superado los monopolios estéticos $[y]$ no hay camisas de fuerza ni limitaciones programáticas" (Morante, 2016: 12), a pesar de "los afanes dogmáticos de no pocos grupos,

\footnotetext{
27 Antologados: Fernando Valverde, Rubén Martín Díaz, Pablo Núñez, Francisco José Martínez Morán, Alejandra Vanessa, Javier Vela, Verónica Aranda, José Alcaraz, María Alcantarilla, Ben Clark, Pablo Fidalgo Lareo, Elena Medel, Javier Vicedo Alós, Constantino Molina Monteagudo, Martha Asunción Alonso, Aitor Francos, Rodrigo Olay, Luna Miguel, Diego Álvarez Miguel, Paula Bozalongo, Javier Temprado Blanquer, Miguel Floriano, Elvira Sastre y Xaime Martínez.

28 Antologados: Sergio C. Fanjuk, Javier Vela, Andrés Catalán, María Alcantarilla, Ben Clark, Luis Llorente, Pablo Fidalgo Lareo, Constantino Molina, Javier Vicendo Alós, Víctor Peña Dacosta, Aitor Francos, Juan Bello, Martha Asunción Alonso, Laura Casielles, Unai Velasco, Francisco José Najarro, María Eugenia Motilla, Berta García Faet, Rodrigo Olay, Diego Álvarez Miguel Ruth Llana, Emily Roberts, Paula Bozalongo, Gonzalo Grajera, Gema Palacios, Xaime Martínez, María Elena Higueruelo y Óscar Díaz.

29 Antologados: Javier Vela, Hasier Larretxea, Laia López Manrique, María Alcantarilla, Pablo López Carballo, Daniel Bernal Suárez, Pablo Fidalgo Lareo, Lola Nieto, Martha Asunción Alonso, Berta García Faet, Sara Torres y Yeray Barroso

30 Álvaro Valverde es el autor del prólogo de Nacer en otro tiempo. Los antólogos escribieron el epílogo.
} 
escuelas o cofradías que, impenitentemente, llevan décadas intentando arrimar el ascua a la sardina de una intransigencia que la mayoría de los jóvenes poetas rechaza como insufrible y manifiesta, en ocasiones de modo muy explícito, no tolerar" (Díaz, 2016: 11). Este rechazo, unido al auge de las redes sociales y de internet, que ha facilitado "las necesidades de expresión y la difusión inmediata de la identidad del autor" (Morante, 2016: 41), ha posibilitado el auge de una lírica que "ha potenciado la subjetividad y la emancipación individual" (Morante, 2016: 41) y que "se distingue por una incesante búsqueda de la originalidad, de un camino personal en medio de la vorágine" (Pera, en Díaz, 2016: 8), a pesar de que, finalmente, "el contexto y el trasfondo social condicionan siempre y es posible percibir una común conciencia generacional" (Morante, 2016: 41), si no poética o ideológica, sí vital (en tanto habitantes de una sociedad insistentemente golpeada por la crisis, la corrupción sistémica, el descrédito de la política o el auge de la posverdad, tan relacionada, por otra parte, con el repunte de las redes sociales).

En este sentido, no creo tanto en la concepción del poema como "una microestructura textual que no da pie a demasiadas mutaciones o innovaciones en la modelización del discurso literario" (Floriano y Rivero Machina, 2016: 226), al menos si nuestra mirada es capaz de sobrepasar los mayoritarios cauces figurativos (a los que tanto atienden Re-Generación y Nacer en otro tiempo) para ser capaces de observar otras propuestas más arriesgadas, de clara vinculación vanguardista y cuya vOz emerge de muy diferentes tradiciones (desde Latinoamérica a las tradiciones silenciarias orientales, pasando por los Language Poets norteamericanos), como sucede con Lola Nieto o Laia López Manrique, entre otras y otros, que sí recoge Rafael-José Díaz en una panorámica que, pese al menor número de antologados, es a nivel estético más amplia que las dos anteriores. Indentikit cabalga desde la poética de tintes experiencialistas de Martha Asunción, concebida como "una mancha que debe ser abrazada para aprender a amar" (Díaz, 2016: 118), hasta la "reducción radical de la dicción" (2016: 70) de Pablo López-Carballo, la paradójica poética de Pablo Fidalgo que habla "descarnadamente y a la vez con el más tierno discurso posible de aquello que constituye el vértice del origen, el transfondo de toda vida" (2016: 92) y que incluso alcanza a Lola Nieto, esa "poeta de los abismos concentrados [que] se lanza a la reverberación de unas sílabas desaforadas" (2016: 50) a partir de un juego constante con la sintaxis espacial y la fragmentación del discurso, como sucede, también, con Lola Nieto y su "poética del desgarro retrospectivamente terapéutico y del desbordamiento como una de las bellas artes" (2016: 104). En este sentido, los poetas seleccionados por Rafael-José Díaz son conscientes de su habitar en un mundo convulso, desmembrado, turbio, que los ha llevado al descreimiento de toda posibilidad de incorporarse a una tradición fijada, cualquiera que esta sea (2016: 14). Aunque publicada bajo el sello Vallejo \& Co, su difusión gratuita y digital a través de Isuu, permite que Identikit escape de la precoz dependencia de las infraestructuras de la industria editorial, lo cual, si en el caso de Luna Miguel y sus posnoventistas permitía una arriesgada apuesta de claros tintes prospectivos, ahora abre la posibilidad de integrar la obra poética de autores cuyas composiciones trabajan sobre la fragmentación y reestructuración del lenguaje, esto es, sobre estéticas que nunca han sido mayoritarias en el campo poético español contemporáneo pero que hoy gozan de un marcado auge (como demuestran el Premio Nacional de Poesía Joven Miguel Hernández 2017 a Ángela Segovia, los doce números de la revista Kokoro y su sello Kriller 71 o la relevancia del Seminario Euraca, en el que participa, entre otras, María Salgado). Las poéticas de tintes vanguardistas siempre han sido concebidas como grietas en el continuum figurativo de la 
historia literaria española, cuyo discurso descalificativo ha impedido "comprender en qué medida lo que al menos una parte de la vanguardias planteaba no era una desconexión de lo real sino, más bien, una relación con lo real en términos de opacidad y de conflicto, y no de claridad o de reconocimiento" (Méndez Rubio, 2004: 40). Es por ello que, a pesar de que tampoco podamos hablar de Identikit en términos de panorámica completa o de reclamo de poéticas de ruptura, sí es fundamental destacar el arrojo de Rafael-José Díaz a la hora de seleccionar a unos poetas que, por su herencia vanguardista y/o desconectada de las tradiciones inmediatamente anteriores de la poesía española, habían quedado al margen de los compendios hasta ahora comentados.

Esta voluntad no la encontramos en Nacer en otro tiempo ni en Re-Generación, que sí están sujetas a las estructuras de la industria editorial. Y es que tanto Renacimiento como Valparaíso Ediciones han mostrado en las últimas fechas una propensión hacia un tipo de poéticas de corte figurativo, cercanas no tanto a la poesía de la experiencia más canonizada como a sus últimas derivas o "rupturas interiores" (trayendo a colación el término ya citado que propuso Luis Antonio de Villena en su antología 10 menos 30 y que ha utilizado Iravedra en algunas de sus reflexiones $[2013,2016])$.

Si atendemos a las líneas de fuerza que Miguel Floriano y Antonio Rivero Machina bosquejan en el epílogo de la antología, podremos comprender hacia qué poéticas se orienta la selección. Primero, dicen, hay un grupo de autores cuya obra orilla "un delicado respeto por la tradición y por la métrica clásica, además de una insólita soltura tanto con el poema estrófico, cuyas bondades y secreta confianza conocen, como con la plasticidad y la relajada cadencia del endecasílabo" (2016: 226), una descripción formal que bien podría acoger a buena parte de la poesía mayoritaria de los años noventa. En este marco incluyen a Xaime Martínez, Rodrigo Olay, Constantino Molina, Martha Asunción Alonso, Gonzalo Gragera, Ben Clark y Andrés Catalán, entre otros, destacando, sin embargo, que su materialización en cada uno de los poetas responde a una concepción en cierta medida personal o individual, alejada de las limitaciones programáticas que sí atravesaron la poesía figurativa de las décadas anteriores a partir de la publicación de manifiestos o textos teóricos bajo que homogeneizaron la práctica poética. En esta cartografía del campo poético, defienden Floriano y Rivero Machina otra parcela caracterizada por la imbricación entre una alta cultura y una cultura de masas, que no se insertan en las composiciones con "el prurito rupturista de las vanguardias del siglo $\mathrm{XX}$, no con la arrogancia culturalista de la mención por la mención", sino "con la misma trascendencia y necesidad con que se evoca la tradición clásica y contemporánea de la bien o mal llamada alta cultura", siempre entendiendo que ambos ámbitos, en una clara afirmación de corte posmoderno, "no son sino la cotidianeidad de sus vidas" (2016: 227). Es este el espacio que habitan Sergio C. Fanjul, Xaime Martínez, Víctor Peña Dacosta, Aitor Francos o Diego Álvarez de Miguel. Tras la descripción de estas dos líneas de fuerza, el discurso de Floriano y Rivero Machina toma una deriva hacia la pluralidad. Así, afirman la existencia de un "tono confesional y directo, ya sea en verso largo y tendido o en un contenido certero" (2016: 227), en casi todos los poetas antologados, destacando en María Alcantarilla, Francisco J. Najarro o Gema Palacios, así como un "claro afán testimonial" que se aprecia en Javier Vela, Pablo Fidalgo, Laura Casielles, Juan Bello, Martha Asunción (de nuevo), Berta García Faet, Paula Bozalongo o Emily Roberts. Es este el momento en que su cartografía del campo comienza a ser más inestable: frente a la pluralidad de voces y estéticas, Floriano y Rivero Machina únicamente entienden que el común denominador entre esta 
amalgama de nombres es el afán testimonial, un rasgo quizás demasiado vago si tenemos en cuenta lo heterogéneo de este último listado, que incluye el nomadismo de Laura Casielles, la poética mayoritariamente experiencial de Paula Bozalongo o Martha Asunción o el verso torrencial, en ocasiones críptico y de clara denuncia social de Berta García Faet. Finalmente, ahondando en esta dispersión, cierran su epílogo con unas breves líneas dedicadas a otros registros o posibilidades: "el aliento hímnico y natural de Luis Llorente, el hondo minimalismo existencial de Javier Vicedo, la metáfora insólita de Unai Velasco o de Ruth Llana, la reflexión serena de María Elena Higueruelo, el corte metafísico de María Eugenia Motilla, la insólita amplitud verbal de Óscar Díaz” (2016: 228).

Así pues, si miramos el mapa de la joven poesía a partir de la leyenda que aquí bosquejan Floriano y Rivero Machina, nuestra visión caminará por las sendas de las tradiciones clásicas, de la unión de la alta y baja cultura (en una poesía pop-posmoderna) y del tono confesional con un afán testimonial, antes de adentrarnos en la espesura y el individualismo de las otras materializaciones. Queda marginada, así, la veta más fragmentaria y rupturista de la poesía más joven del panorama, que no es siquiera incluida en las páginas de Nacer en otro tiempo (Lola Nieto, Alba Ceres, María Salgado, Ángela Segovia, etc.); la línea continuadora de la poesía de la conciencia crítica, puesto que, pese a que sí está Sergio C. Fanjul, incluido por Alberto GarcíaTeresa en Disidentes, Floriano y Rivero Machina priorizan más su vertiente pop ("Alicia en el país de las redes sociales") que su cariz heterodoxo (a su vez, tampoco podemos decir que esta sea una arriesgada apuesta de los antólogos o una reivindicación de una poética cercana a la conciencia crítica, pues debemos tener en cuenta que su inclusión en el catálogo de Visor con Pertinaz freelance lo ubica ya por completo en un importante espacio del campo poético no demasiado transitado por los jóvenes poetas que difícilmente puede ser esquivado por un antólogo que quiera dar una visión un tanto panorámica); tampoco encontramos referencia alguna a la tradición silenciaria, tan reclamada a partir del magisterio de José Ángel Valente o Chantal Maillard por ejemplo, por muchas otras autoras no incluidas, como Alba Ceres. Es cierto, que "toda antología, y esto ya se ha reiterado con frecuencia, es un error, lo mismo, acaso, que toda decisión también lo es, quizás por lo que, ondeando en el vacío, deja atrás" (Floriano y Rivero Machina, 2016: 225). Ahora bien, no por ello debemos dejar de focalizar en la fotografía ofrecida y en su fuera de plano. Al fin y al cabo, también estos compendios parten de una ideología poética (explicitada o no) que participa de las luchas por la hegemonía y por el poder siempre presentes en el campo poético y que pueden contribuir a iluminar determinados espacios y, por consiguiente, a oscurecer otros, con las consiguientes implicaciones de todo ello en los procesos de canonización actuales y futuros.

El mosaico que ofrece José Luis Morante en Re-generación. Antología de poesía española (2000-2015) es, en lo esencial, de similares características al de Floriano y Rivero Machina. Al igual que sucedía en Nacer en otro tiempo, un simple vistazo al índice de antologados nos indica una mayoritaria presencia de poéticas figurativas: Fernando Valverde, Elena Medel, Ben Clark, Martha Asunción, Diego Álvarez Miguel o la poeta best-seller Elvira Sastre, junto a otras y otros, conforman una amplia "comunidad de voces sobre un escenario plural donde coinciden la realidad exterior y la interior" (Morante, 2016: 41). Podemos hablar de ella en tanto una antología panorámico-histórica con tintes programáticos (ambas, como dijera Ruiz Casanova, se encuentran en espacios muy similares e, incluso, sobrepuestos): panorámica-histórica por la 
voluntad de recoger la obra de una serie de poetas pertenecientes a un mismo marco cronológico; programática, en tanto legitima unas determinadas prácticas poéticas (aun sin explicitarlo en ningún momento del extenso prólogo y sin querer hacer de ello generación o grupo como tales).

Valparaíso y Renacimiento, con José Luis Morante y Miguel Floriano-Antonio Rivero Machina como coordinadores, respectivamente, ofrecen dos antologías que ponen el foco en las derivas y continuaciones del paradigma figurativo-experiencial, al igual que sucediera en buena parte de las compilaciones de los años ochenta, noventa y dos mil con relevantes firmas como las de Luis Antonio de Villena o José Luis García Martín a la cabeza. Si a ello se une el apadrinamiento de buena parte de los poetas de la experiencia a la nueva corriente de poesía de best-seller, mediante la escritura de prólogos por parte de Benjamín Prado y Joan Margarit en dos libros de Elvira Sastre, la concesión del Premio Ciudad de Melilla a Loreto Sesma o la realización del webdoc "Memoria de futuro", con la participación de Luis García Montero, Elvira Sastre, Marwan, Escandar Algeet, Carlos Pardo y Guille Galván, o el apoyo de los grandes sellos editoriales a poetas cercanos a la estética (recordemos las obras completas de Valverde y Medel publicadas en Visor) no cabe duda de que nos encontramos, de nuevo, sobre un campo poético cuyas fuerzas se dirigen hacia una (re)canonización y (re)actualización de las poéticas experienciales-figurativas. Nada nuevo, por otra parte, si volvemos a aquellas primeras reflexiones en torno a los juegos de poder generados en el campo cultural español tras el proceso transicional. Sin embargo, no por ello debemos dejar de bucear entre estos productos culturales que, recordemos, han marcado las principales sendas de la historia literaria de nuestro país desde hace décadas. Más si cabe en un momento de cambio y de renovación de nombres como el actual: las cartas que cada uno de los actores juegue en el campo poético, en este preciso instante en el que las poéticas más jóvenes ya tienen voz en el panorama, marcarán el devenir futuro de la poesía española. Y en ello, el papel de la crítica es insustituible: como lo es el de las instituciones, el de la industria editorial, el del periodismo cultural, el de la academia, etc.

No es de extrañar que ante tales movimientos editoriales hayan surgido reacciones. Quizás, la más relevante de ellas es la que han protagonizado los poetas afines a Kokoro con la creación del sello editorial Kriller71 que en marzo de 2017 editó Voz vértebra. Antología de poesía futura. Dirigida por Laia López Manrique, Antonio Francisco Rodríguez Esteban y Lola Nieto, Kokoro se define como un espacio que "acoge las lenguas huérfanas, abre el espacio para lo híbrido, lo mezclado, lo impuro, lo no catalogable por las taxonomías profilácticas trazadas por la lengua de poder”. Es, en este sentido, un refugio para las poéticas experimentalistas que de-re-construyen el lenguaje en cada poema y comunican con una lengua entrecortada, sesgada e incluso paradójicamente muda (que dice y calla al mismo tiempo), una dicción híbrida que devasta el lenguaje, tras Benjamin (1990: 161), no por mero apetito destructivo, sino para encontrar el camino que discurre a través de sus ruinas en un intento de señalar un más allá de la palabra institucionalizada. Voz vértebra recoge buena parte de estas poéticas. Y lo hace con un juego borgiano o, en palabras de Tania Panés (2017), de agresivo desdoblamiento que transgrede los límites temporales y editoriales conocidos; un juego en que de la maniobra deconstructiva brota una sonrisa irónica: frente al nombre por el nombre, es decir, frente a la autoría en mayúsculas, pone en primera línea el anonimato (¿Quién es Kaylani Amihan Chandra o Aizhan Maizhilis?) al "hacer pasar este libro no como lo que es, la irrupción de un futuro a veces remoto en el pasado, sino como un juego elaborado en la más estricta contemporaneidad" (VVAA, 2017: 17); frente al consumo pasivo del 
lector, un juego reconstructivo que parte de la aparente necesidad de (re)nombrar los pseudónimos ${ }^{31}$; frente a la fotografía hecha en el aquí y el ahora del intercambio comunicativo, la nada inocente travesura de afirmar que Voz vértebra es la antología de la habitante del futuro Ayganim Katharmova:

La antóloga Ayganim Katharmova, procedente del octavo milenio (era del Xenoceno, con su veneración al Afuera abisal), se ha encargado de recopilar esta información y enviarla a su pasado para su publicación en soporte de papel de celulosa: un experimento transtemporal para indagar en la inquieta y no pocas veces inquietante condición humana. En el futuro la escritura sufre varias mutaciones y cambian los soportes: se abandona el papel y aparece el éter cuneiforme, los palimpsestos psíquicos, las redes epidémicas teriomorfas. Con el paso de los milenios, la propia noción de realidad se desmorona, muta el concepto de cuerpo y la idea misma de vida... (La tribu, 2017)

En definitiva, "un libro donde el editor se autodestruye como un Ave Fénix para resurgir como Ayganim Katharmova, que ha venido del futuro para hipnotizar a los editores de Kokoro y convencerles de que publiquen una antología seleccionada cuidadosamente por ella misma y ver qué posibles efectos puede tener esta poesía del futuro en nuestras mentes toscas y primitivas" (Panés, 2017). Esto es, un compendio que dinamita, como ya hiciera buena parte de la teoría literaria, la propia noción de escritor (e incluso de sujeto, tras la estela, quizás, de Foucault): "a partir del quinto milenio el Yo es sustituido por nano-psiques fractales como anillos engarzados que supuran conciencia. [...] El Yo queda como una reliquia arqueológica, una resonancia de los tiempos míticos (psicológicos)" (VVAA, 2017: 195). Desde este futuro, son lanzadas hacia nuestro presente diversas etiquetas, como la poesía tectónica ("un método de escritura que pretende subvertir las raíces mismas del pensar y el sentir, liberándolos de los corsés sentimentales, el monopolio de la razón, los apriorismos reflexivos, los prejuicios que gobiernan una cultura mental que, en pleno tránsito hacia otro paradigma, no acierta a desarraigar sus cegueras, sus temores, su hambre no saciada su sueño dogmático" [VVAA, 2017: 33-34]), los poetas asincronos, los autores del New Stigmata ("que se mutilan y se inoculan atroces enfermedades víricas para explorar la relación entre lenguaje y enfermedad" [VVAA, 2017: 205]), la poesía epidérmica (escrita con el cuerpo), la poesía táctical vegetal, etc., es decir, un completo universo ficcional del que brota una irónica lectura del campo poético presente y, sobre todo, de sus aparatos críticos.

Frente a las antologías al uso (a caballo, decíamos, entre lo programático y lo históricopanorámico) que han copado en los últimos años los anaqueles de las librerías, Voz vértebra ha emergido con una voluntad no solo de ruptura (borgiana, si se quiere) y de crítica (desde la toma de conciencia de la crisis de la representación), sino también de reivindicación de un grupo de escritores que conciben la poesía como un perpetuo trabajo con su materia prima: esto es, una poética fundamentada en la fragmentación y reestructuración del lenguaje: "Sea como sea, el futuro no puede existir sin una experimentación vital y lingüística. El lenguaje, la paz política y

\footnotetext{
${ }^{31}$ Los poetas recopilados, que se esconden tras la extraña nómina de nombres de la antología, son: Begoña Callejón, Alba Ceres, Sergi de Diego Mas, Berta García Faet, Uxue Juárez, David Leo García, Chantal Maillard, Laia López Manrique, Rubén Martín, Layla Martínez, Ruth Llana, Lola Nieto, Francisco Jota-Pérez, Raúl Quinto, Esther Ramón, Marco Antonio Raya, Antonio F. Rodríguez, María Sánchez, Regina Salcedo, Ángela Segovia, Sara Torres, Su Xiaoxiao.
} 
social, el respeto por la vida en todas sus formas y el despertar de la conciencia irán de la mano inevitablemente. El lenguaje es la clave esencial para entender el vasto Universo de la mente humana y todas sus maravillosas incongruencias" (Panés, 2017). Este cariz contestatario lo ejemplifica, entre muchas otras, la antologada María de Águila (pseudónimo) que vive recluida en su casa del octavo milenio, que nunca ha salido de su pueblo y que nunca ha recibido educación primaria, tal y como lo señala Tania Panés: "he aquí una brutal crítica hacia la educación y sistema político de este país así como el peso de la religión católica, una política demencial y circense además de absolutamente corrupta, el sufrimiento de la Guerra Civil y una posterior dictadura que todavía hoy (y en el futuro) sigue haciendo de España un territorio hostil, devastado, casi inhabitado y pobre" (Panés, 2017). El cariz de denuncia socio-política de Voz vértebra se acrecienta "cuando más adelante se relata cómo los habitantes de algunos planetas son esclavizados para explotar recursos y materia prima para el goce y disfrute de los ciudadanos de lujosas metrópolis de otros planetas, tal y como ocurre hoy en día con los millones de niñas/ niños / adolescentes / hombres / mujeres que son explotados para fabricar ropa o extraer coltán y azufre en condiciones infrahumanas" (Panés, 2017). Así, nos encontramos ante una de las pocas (si no la única) antología que solicita con más autenticidad un sentimiento, quizás no grupal (al fin y al cabo, no podemos hablar todavía de Kokoro como una agrupación de poetas con una poética y unos objetivos comunes) pero sí, sin duda, común o colectivo, en tanto los antologados (así como buena parte de los no incluidos que han participado en los doce números de la revista) comparten un parecido sistema de pensamiento sobre el acto poético: ruptura del discurso, recursos logofágicos, sintaxis espacial, fragmentación, relectura de las tradiciones vanguardistas y silenciarias, etc. No es extraño que así sea si tenemos en cuenta que la defensa de tales poéticas debe llevar aparejada una sustancial carga teórica y crítica que refrende su posicionamiento en un campo poético como el español, mayoritariamente fundamentado en los paradigmas figurativos. Si en la lucha por la hegemonía del campo, buena parte de las antologías y de los poetas antes comentados se acogían a la carga teórica desarrollada por los poetas de las generaciones anteriores (recordemos los paralelismos entre Fernando Valverde y Luis García Montero, por ejemplo), los autores de Kokoro y Voz vértebra deben construir un nuevo espacio de referencia que retome corrientes de pensamiento habitualmente alejadas de los cauces mayoritarios (de ahí la inclusión de Chantal Maillard en el compendio). No en vano, Rosa Maldonado utiliza una significativa cita de la autora de Matar a Platón:

No es posible pensar cor-recta-mente, con la mente en línea recta. Pensar siempre es una indisciplina. Cuando se piensa de verdad, se abre una brecha en el discurso que ya había. Se piensa con un quiebro. $\mathrm{Y}$ en ese quiebro, quien piensa padece el quiebro al mismo tiempo. Es él quien se quiebra, y el sentir le aporta los instrumentos para el cambio. Su mesa de operaciones está dispuesta: vivir no es suficiente (Maldonado, 2017)

A su vez, es significativo que Kokoro haya necesitado crear su propio sello editorial (Kriller 71) para publicar esta antología. Lo arriesgado de la propuesta ha generado una clara dificultad para entrar en los cauces de difusión mayoritarios, que sí han tenido las propuestas de Floriano y Rivero Machina (Renacimiento) y Morante (Valparaíso Ediciones) o, si atendemos a las antologías diacrónicas del apartado anterior, Humanismo solidario, Poetas ante la incertidumbre o El canon abierto (las tres en Visor). Ahora bien, las causas no dependen únicamente de los engranajes de la industria editorial, sino también de una voluntad propia de los autores de Kokoro: la de participar 
en el campo poético desde un espacio no atado a las cortapisas de los grandes sellos editoriales, sino desde un área controlada, creada y fomentada por ellos mismos. Conscientes, por supuesto, de las implicaciones de proyectar sobre el campo poético español una marcada voluntad de vanguardia:

La exclusión (o su reducción a un lugar accesorio) de las escrituras poéticas de vanguardia en el canon historiográfico español pone al descubierto razones teóricas y críticas más profundas que conviene tener en cuenta. ¿Es preciso recordar que la escritura vanguardista, y con ella su diverso grado de excepcionalidad, tiende muy a menudo a cuestionar y diluir los planteamientos unidireccionales, distorsionando estatutos críticos y poéticas tendentes a uniformizar (dar coherencia) panoramas donde impera la diferencia? Romper la conciencia de armonía (el simulacro o la ilusión de armonía) supone introducir, frente a la inmovilidad y la automatización, la divergencia o la idea de fractura, el fenómeno de una diferencia adherida al cambio permanente de valores, al contraste, al disenso, a la agitación y al conflicto en un periodo histórico que, en su omnisignificación canónica, se quiere reducido a consensos esencialistas o hegemónicos [...] De ahí que, en la historiografía literaria, en las antologías y su pretendida institucionalización, introduzcan elementos divergentes que, en muchos casos, cuestionan los planteamientos selectivos, con sus correspondientes restricciones canónicas y hermenéuticas, de historiador o antólogo (Pont, 2005: 258-259)

Kokoro brota de estos espacios descritos por Jaume Pont, al igual que lo hace Voz vértebra y, en este sentido, dialoga con las otras antologías en el panorama que habitamos: un campo poético en constante ebullición donde las propuestas antológicas se suceden en una suerte de reactualización perpetua de la lucha por las premisas y por la hegemonía que ha marcado este espacio en las últimas décadas. Los poetas, los críticos y los antólogos son conscientes de la importancia de la práctica antológica en el juego de fuerzas del campo, más, si cabe, en un momento como el actual, en el que se publican cada año centenares de poemarios y se dan a conocer varias decenas de poetas. Frente a este boom de la poesía, la antología tiene de nuevo un papel fundamental: en la mano de los antólogos está utilizar este poder en una u otra dirección; en las manos de la crítica, señalar de qué forma sus decisiones tienen relevancia en los procesos de canonización y en la incesante (re)escritura de la historia literaria.

\section{A MODO DE CONCLUSIÓN (TODAVÍA PARCIAL)}

gritar hacer

que el mundo no

sea una vez más el mundo

(Antonio Méndez Rubio, 2007: 27)

Dice Sánchez Robayna que la sociología y el pensamiento crítico ven en la complejidad, la inestabilidad y la incertidumbre algunos de los elementos con los que debemos convivir en la cultura contemporánea, pero que, no por ello, debemos dejar de examinar los fenómenos que en ella acaecen: "Diríamos más bien lo contrario: precisamente por eso estamos en la obligación de examinarlos" (Sánchez Robayna, 2005: 14). Si a ello hemos querido lanzarnos en este artículo es por la constatación, tal y como se indicaba en la convocatoria de este número, de que han sido pocas las ocasiones en las que algunos aventureros han roto el silencio y se han atrevido a caminar por el desierto. Esta escasez de miradas está íntimamente ligada a la cercanía temporal, 
por supuesto, pero no debe ser ello la excusa para apartar la vista de un fenómeno en plena construcción, cuyas consecuencias en el campo poético actual estamos observando día a día.

Lo antológico, tal y como se ha visto, ha marcado desde hace décadas el devenir de la historia literaria en España y de los procesos de canonización, a partir del "frotamiento y la repetición de nombres y esquemas [...] donde es la circulación y no el discurso que circula, el principal argumento de autoridad" (Talens, 1989: 55). Tales devaneos han sido aquí repasados desde la publicación de Nueve novísimos poetas españoles, cuya estrategia de marketing (Carnero, 1983), de publicitación (Talens, 1989) y de etiquetado (Méndez Rubio, 2004b; López Merino, 2008; Prieto de Paula, 1996) fue asimilada por los principales antólogos y críticos de las décadas posteriores en sus constantes ejercicios de legitimación de la corriente figurativa mayoritaria (Luis Antonio de Villena o José Luis García Martín): "Lo que al principio constituye un movimiento más o menos espontáneo de escritores jóvenes que tratan de buscar un espacio propio y evolucionar al margen de sus mayores, se domestica y petrifica rápidamente en manos de un antólogo prestigiado socialmente a quien preocupa, sobre todo, controlar el movimiento de las promociones que le suceden" (Doce, 2005: 292-293). En este sentido, las dos antologías de Luna Miguel, la de Floriano y Rivero Machina y la editada desde Kokoro son todavía la obra de jóvenes antologando jóvenes (como también lo es Lecturas del desierto, que acompaña a este monográfico). Ahora bien, tal entrada de críticos prestigiosos sí se atisba en Re-generación, de José Luis Morante, así como en buena parte de los compendios que han recogido autores nacidos a partir del ochenta junto a otros anteriores: Humanismo solidario, por ejemplo, de Remedios Sánchez García y Marina Bianchi, o El canon abierto, también de Remedios Sánchez García, acompañada ahora por Anthony L. Geist.

El modelo programático de Nueve novísimos, tan transitado en las antologías de los ochenta y los noventa, no tiene una continuidad como tal en las últimas compilaciones: quizás Humanismo solidario y Poetas ante la incertidumbre sí señalan líneas poéticas comunes, con algunos tintes grupales que pueden permitir a otros autores sumarse a sus nóminas; Luna Miguel, pese a presentar el concepto posnoventismo, no focaliza, como se ha visto, en la definición de unas pautas generacionales, más allá del argumento temporal; Voz vértebra, por su parte, recoge poéticas similares en una suerte de reclamo de una entendimiento colectivo o común del hecho poético, que solo el tiempo nos dirá si deriva en la conformación de un nuevo grupo.

Con todo ello, se ha perdido el diálogo conflictivo (abiertamente ideológico, si se quiere) de la poesía inmediatamente anterior, para asistir al auge de la "convivencia sosegada de idearios" que afirmaba Morante (2016: 12) y a la decadencia de lo generacional-grupal en los últimos años. Ahora bien, sí hemos podido constatar una inercia ya presente en las décadas anteriores: la de legitimación desde lo antológico de las prácticas figurativas. Si López Merino afirmaba que la estrategia vencedora en la batalla por escribir de la poesía de los últimos lustros, había sido la de los poetas figurativos (2008: 59), a día de hoy, diez años después, podemos al menos constatar que a nivel antológico y de atención crítica también han sido las prácticas que orillan lo figurativo las más atendidas (salvo, de nuevo, en el caso de Voz vértebra, en algunos momentos de Identikit y de La poesía posnoventista española en 15 voces) y las que han sido incluidas en los compendios con mayor difusión editorial (Renacimiento y Valparaíso; frente a dos ediciones digitales y una edición en el sello propio Kriller71). En este hecho se conjugan, como se ha visto, varios detalles: 
primero, la ya estudiada ideología del campo cultural y poético postransicional; segundo, la ideología de la industria editorial española, asimilada a este discurso mayoritario del campo cultural y poético, que ha incluido en sus catálogos aquellas propuestas auspiciadas por las instituciones, en una suerte de simbiosis que ha contribuido al empuje de determinados procesos de canonización; tercero, la ideología del antólogo que, en los compendios de mayor difusión tiende a asimilarse a la de la industria editorial; y, cuarto, el "deseo desmesurado del joven poeta de verse asimilado a una determinada tendencia o corriente, pues de lo contrario corre el riesgo de quedarse fuera de los recuentos panorámicos, de los árboles clasificatorios, de los manuales y antologías" (Doce, 2005: 298-299).

La emergencia de centenares de nuevos poemarios año tras año y de decenas de autores va a llevar aparejada la publicación de nuevas y (esperemos) variadas antologías. En tanto herramienta que nos permita ver más allá de lo aparente, la labor de la crítica se antoja necesaria en este proceso en marcha, pues recordemos que la historia de la poesía reciente, como dijera Falcó, ha sido escrita desde las antologías (2007: 26). Ya Vázquez Montalbán supo apreciarlo en la poética que incluyó en Nueve novísimos poetas españoles allá por 1970, cuando afirmó en la cita que he utilizado para abrir este artículo: "Las antologías sí que se leen. Creo que a partir de ahora solo escribiré antologías” (Castellet, 2011: 57). Exagerada, tal vez, y, sin embargo, también cargada de razones. 


\section{BIBLIOGRAFÍA}

ABril, Juan Carlos (ed.) (2008). Deshabitados. Antología de poesía española joven. Granada: Maillot Amarillo.

Adorno, Theodor (2004). Minima moralia: reflexiones desde la vida dañada. Obra completa 4. Madrid: Akal.

Aguado, Jesús (2016). Fugitivos. Antología de la poesía española contemporánea. Madrid: Fondo de Cultura Económica.

Aguilar, Paloma (1996). Memoria y olvido de la Guerra Civil española. Madrid: Alianza Editorial.

Alicia Bajo Cero (1996). Poesía y poder. Valencia: Ediciones Bajo Cero.

Althusser, Louis (1974). Ideología y aparatos ideologicos de estado: notas para una investigación. Barcelona: Seminario del Instituto de Estudios Laborales.

Amorós, Amparo (1989). "¿Los novísimos y cierra España! Reflexión crítica sobre algunos fenómenos estéticos que configuran la poesía de los años ochenta”. Ínsula 512-513: 63-67.

ANDRADE BLANCO, Juan Antonio. "Renuncias y abandonos en la evolución ideológica durante la Transición a la Democracia: una propuesta para el estudio del IX Congreso del PCE y el congreso extraordinario del PSOE", HAOL 8 (2005): 43-50.

BAguÉ Quílez, Luis y SANTAMARíA, Alberto (2013). "2001-2012: una odisea en el tiempo". Bagué Quílez, Luis y SANTAMARÍA, Alberto (coords.). Malos tiempos para la épica. Última poesía española (2001-2012). Madrid: Visor: 11-32.

BAguÉ, Luis (ed.) (2012). Quien lo probó lo sabe: 36 poetas para el tercer milenio. Zaragoza: Institución Fernando el Católico.

BANEGAS, Rafael (2011). Inciertas conclusiones. Barcelona: Temenos.

BATLLÓ, José (ed.) (1968). Antología de la nueva poesía española. Barcelona: Lumen.

Benjamin, Walter (1975). Tentativas sobre Brecth. Iluminaciones III. Madrid: Taurus.

BENJAMIN, Walter (1990). Discursos interrumpidos I. Madrid: Taurus.

BiAnCHI, Marina (2016). "El Humanismo Solidario: el compromiso con el hombre desde la poesía, en el siglo XXI". SÁnCHEZ, Remedios (coord.). Palabra heredada en el tiempo. Tendencias y estéticas en la poesía española contemporánea (1980-2015). Madrid: Akal: 427-438.

BOLAÑO, Roberto (2006). Los perros románticos. Barcelona: Acantilado.

BOuRDIEU, Pierre (1995). Las reglas del arte. Génesis y estructura del campo literario. Barcelona: Anagrama.

BOURDIEU, Pierre (2001). Contrafuegos II. Barcelona: Anagrama.

CARNERO, Guillermo. "La corte de los poetas". Revista de Occidente 23 (1983): 45-48.

CASTEllet, Josep Maria (ed.) (2011). Nueve novísimos poetas españoles. Barcelona: Península.

Clark, Ben (2006). Los hijos de los hijos de la ira. Madrid: Hiperión.

CORREYERO, Isla (eda.) (1998). Feroces. Radicales, marginales y heterodoxos en la última poesía española. Barcelona: DVD.

DeBORD, Guy (2002). La sociedad del espectáculo. Valencia: Pre-Textos.

DíAZ, Rafael-José (ed.) (2016). Identikit. Muestra de poesía española reciente. Digital: Vallejo \& Co. 
DiegO, Gerardo (2007). Poesía española [Antologias]. Madrid: Cátedra.

DoCE, Jordi (2005). "Poesía española hoy: de la arbitrariedad a la domesticación". SÁNCHEZ ROBAyna, Andrés y DOCE, Jordi (eds.). Poesía hispánica contemporánea. Ensayos y poemas. Barcelona: Galaxia Gutemberg: 285-308.

ESPINOSA, Santiago (2016). "Una aventura trasatlántica. Poetas y poesía ante la incertidumbre". SÁNCHEZ, Remedios (coord.). Palabra heredada en el tiempo. Tendencias y estéticas en la poesía española contemporánea (1980-2015). Madrid: Akal: 315-327.

Europa Press. "'Los hijos de los hijos de la ira' de Ben Clark y 'Urbi et orbi'de David Leo García, Premio de Poesía Hiperión” Europapress (21/03/2006).

Even-Zohar, Itamar (1990). Polysistem Studies, volumen monográfico de Poetics Today, 11, 1.

FALCÓ, José Luis. “1970-1990: de los novísimos a la generación de los 80”. Ínsula 721-722 (2007): 26-29.

FALCÓ, José Luis y RuBIO, Fanny (eds.) (1981). Poesía española contemporánea (1939-1980). Madrid: Editorial Alhambra.

FALCÓN, Enrique (ed.) (2007). Once poetas críticos en la poesía española reciente. Tenerife: Baile del Sol.

FALCÓN, Enrique (2010). Las prácticas literarias del conflicto: Registro de incidencias (1991-2010). Madrid: La oveja roja.

Floriano, Miguel y Rivero Machina, Antonio (eds.) (2016). Nacer en otro tiempo. Antología de la joven poesía española. Sevilla: Renacimiento.

FOUCAULT, Michel (1997). La arqueología del saber. México: Siglo XXI Editores.

FOUCAULT, Michel (2006). Sobre la Ilustración. Madrid: Tecnos.

GAHETE JURADO, Manuel (2016). "Tradición y modernidad en Humanismo Solidario". SÁNCHEZ, Remedios (coord.). Palabra heredada en el tiempo. Tendencias y estéticas en la poesía española contemporánea (1980-2015). Madrid: Akal: 403-414.

GARCíA, Miguel Ángel (2017). "Historiografía, canon, compromiso: los poetas del 27 en las antologías (1932-1965)". GARCíA, Miguel Ángel (coord.). El compromiso en el canon. Antologías poéticas españolas del último siglo. Valencia: Tirant Humanidades: 15-77.

GARCía MARTín, José Luis (ed.) (1980). Las voces y los ecos. Madrid: Ediciones Júcar.

García Martín, José Luis (ed.) (1988). La Generación de los Ochenta. Valencia: Mestral.

García Martín, José Luis (1992). "La poesía". Villanueva, Darío (ed.). Historia y crítica de la literatura española. Los nuevos nombres: 1975-1990. Vol. 9. Barcelona: Crítica: 94-156.

García MARTín, José Luis (ed.) (1995): Selección nacional. Última poesía española. Gijón: Llibros del Pexe.

GARCía MARTín, José Luis (ed.) (1996). Treinta años de poesía española (1965-1995). Granada: Renacimiento/La Veleta.

García Martín, José Luis (ed.) (1999). La generación del 99. Antología crítica de la joven poesía española. Oviedo: Nobel.

García Montero, Luis (1993a). Confesiones poéticas. Granada: Maillot Amarillo.

García Montero, Luis (1993b). "¿Por qué no sirve para nada la poesía? (Observaciones en defensa de una poesía para los seres normales". GARCía MONTERO, Luis y MUÑOz MolinA, Antonio. ¿Por qué no es útil la literatura?. Madrid, Hiperión: 9-41.

GARCíA POSADA, Miguel (ed.) (1996). La nueva poesía (1975-1992). Barcelona: Crítica. 
García-Teresa, Alberto (2013). Poesía de la conciencia crítica (1987-2011). Ciempozuelos (Madrid): Tierradenadie Ediciones.

García-Teresa, Alberto (ed.) (2015). Disidentes. Antología de poetas críticos españoles (1990-2014). Madrid: La Oveja Roja.

GONZÁLEZ, Ángel (1999). "Afirmación, negación y síntesis: coherencia del proceso creativo de Antonio Machado". VVAA. Antonio Machado. Madrid: Alfaguara: 177-188.

GonZÁLEZ, David y Boix, Eduardo (eds.) (2011). Heterogéneos: poemario colectivo. Tenefife: Ediciones Escalera.

GonzÁlez moreno, Pedro A. (2016). La musa a la deriva. Castilla y León: Junta de Castilla y León.

GoÑI, Javier. "De Villena se arriesga con una antología de jóvenes poetas". El País (25/04/1997).

GuILLÉN, Claudio (1985). Entre lo uno y lo diverso. Introducción a la literatura comparada. Barcelona: Crítica.

Hartog, François (2007). Regímenes de historicidad. Presentismo y experiencias del tiempo. México: Universidad Iberoamericana.

IgLESIAS, Monserrat (1994). "El sistema literario: Teoría Empírica de la Literatura y Teoría de los Polisistemas". Villanueva, Darío (ed.). Avances en teoría de la literatura (Estética de la Recepción, Pragmática, Teoría Empirica y Teoría de los Polisistemas). Santiago de Compostela: Universidad de Santiago de Compostela: 309-356.

IRAVEDRA, Araceli. "Palabras de familia gastadas tibiamente. Sobre la disolución de un paradigma o la diáspora estética de la poesía de la experiencia". Revue Romane 43:2 (2008): 286-302.

Iravedra, Araceli (2010). El compromiso después del compromiso. Poesía, democracia y globalización (poéticas 1980-2015). Madrid: UNED.

IRAVEDRA, Araceli (2013). "Después de este desorden impuesto o las voces del posfranquismo (El canon del compromiso y el compromiso con el canon)". Iravedra, Araceli (eda.), Politicas poéticas. De canon y compromiso en la poesía española del siglo XX. Madrid: Iberoamericana: 203-255.

IRAVEDRA, Araceli (eda.) (2016). Hacia la democracia: la nueva poesía (1968-2000). Madrid: Visor Libros / Centro para la Edición de los Clásicos Españoles.

IraVEDRA, Araceli (2017). "Au-dessus de la mêléee? Compromiso, canon y antologías poéticas en la escena del postfranquismo". García, Miguel Ảngel (coord.). El compromiso en el canon. Antologias poéticas españolas del último siglo. Valencia: Tirant Humanidades: 183-224.

JimÉNEZ HEFFERNAN, Julián (2004). "Literatura en España 1939-2000". VVAA. Historia de la Literatura. Vol. VI. El mundo moderno: 1914 hasta nuestros días. Madrid: Akal: 426-505.

Josephs, Allen y PALACios, Luis David (2016). "Poesía ante la incertidumbre. La resistencia y la necesidad de una semiótica de la emoción". SÁNCHEZ, Remedios (coord.). Palabra heredada en el tiempo. Tendencias y estéticas en la poesía española contemporánea (1980-2015). Madrid: Akal: 329-335.

KLEIN, Naomi (2012). La doctrina del shock: el auge del capitalismo del desastre. Barcelona: Paidós.

LA Tribu. "Voz vértebra. Antología de poesía futura. VVAA". La Tribu. Un cuarto propio compartido (18 de octubre de 2017).

LABRADOR, Germán (2017). Culpables por la literatura. Imaginación politica y contracultura en la Transición española (1968-1986). Madrid: Akal. 
LANZ, Juan José. "Primera etapa de una generación. Notas para la definición de un espacio poético: 1977-1982”. Ínsula 565 (1994): 3-6.

LANZ, Juan José. "La joven poesía española. Notas para una periodización”. Hispanic Review 66 (1998): 261-287.

LLOYD, David y Thomas, Paul (1997). Culture and State. Londres: Routledge.

LÓPEZ MERINO, Juan Miguel: "Hacer historia: Crítica literaria y poesía posfranquista”, Tonos Digital, 15 (2008): 1-48.

LYOTARD, Jean-Françoys (1984). La condición postmoderna: informe sobre el saber. Madrid: Cátedra.

MAINER, José-Carlos (ed.) (1999). El último tercio del siglo (1968-1998) Antología consultada de la poesía española. Madrid: Visor.

Maldonado, Rosa. "Voz vértebra. Antología de poesía futura. Kokoro Libros / Kriller71ediciones". Transtierros (7 de noviembre de 2017).

Martín Pardo, Enrique (ed.) (1967). Antología de la joven poesía española. Madrid: Pájaro de Cascabel.

Martín PARdo, Enriqeu (ed.) (1970). Nueva poesía española. Madrid: Scorpio.

MARTínEZ, Guillem (coord.) (2012). CT o la Cultura de la Transición. Barcelona: Mondadori.

MARTínez FERnÁNDEZ, Ángela. “La escritura del shock. Crisis y poesía en España”. Kamchatka. Revista de Análisis Cultural 4 (2014): 383-434. (DOI:10.7203/KAM.4.4294)

Martínez Sarrión, Antonio (2002). "Prólogo". Riechmann, Jorge. Poema de uno que pasa. Valladolid: Fundación Jorge Guillén: 6-12.

MÉndez Rubio, Antonio. "Memoria de la desaparición: notas sobre poesía y poder". Anales de literatura española 17 (2004a): 121-144.

MÉndez Rubio, Antonio (2004b). Poesía sin mundo. Mérida: Editorial Regional de Extremadura.

Méndez Rubio, Antonio (2007). Para no ver el fondo. Tenerife: Ediciones Idea.

MÉNDEZ RuBio, Antonio (2008). La destrucción de la forma ( $Y$ otros escritos sobre poesía y conflicto). Madrid: Biblioteca Nueva.

MÉndez Rubio, Antonio (2012). La desaparición del exterior. Cultura, crisis y fascismo de baja intensidad. Zaragoza: Eclipsados.

Menéndez Pelayo, Marcelino (2014). "Proyecto de una nueva Antología de poesías selectas castellanas. Enumeración y juicio de las principales colecciones existentes". Rodríguez Sánchez de León, María José (ed.). Menéndez Pelayo y la literatura: estudios y antología. Madrid: Editorial Verbum: 392-413.

Miguel, Luna (ed.) (2011). Tenían veinte años y estaban locos. Córdoba: La Bella Varsovia.

Miguel, Luna (ed.) (2014). La poesía posnoventista española en 15 voces.

Molina Campos, Enrique. "La poesía de la experiencia y su tradición". Hora de Poesía 59-60 (1988): 41-47.

MORA, Vicente Luis (2006). Singularidades. Ética y poética de la literatura española actual. Madrid: Bartleby.

Morales BARBA, Rafael (ed.) (2006). Última poesía española (1990-2005). Madrid: Marenostrum. 
MORALES LOMAS, Francisco (2016). "El Humanismo Solidario. Una poética para el siglo XXI". Sánchez, Remedios (coord.). Palabra heredada en el tiempo. Tendencias y estéticas en la poesía española contemporánea (1980-2015). Madrid: Akal: 381-392.

MORALES LOMAS, Francisco. “La poesía de Fernando Valverde (1997-2017)”. Poéticas II, 6 (2017): 127-135.

Morante, José Luis (ed.) (2016). Re-generación. Antología de poesía española (2000-2015). Granada: Valparaíso Ediciones.

OrTega, Antonio (1994). La prueba del nueve. Madrid: Cátedra.

PANÉs, Tania. "Voz vértebra (Antología de poesía futura): La posible poesía imposible". Oculta Lit (23 de mayo de 2017).

Pacheco, José Emilio. “Poesía ante la incertidumbre”. Proceso 1810 (10 de julio de 2011): 62-63.

PONT, Jaume (2005). "La poesía hispánica de vanguardia y la formación del canon”. Sánchez Robayna, Andrés y Doce, Jordi (eds.). Poesía hispánica contemporánea. Ensayos y poemas. Barcelona: Galaxia Gutemberg: 245-273.

Pozuelo Yvancos, José María. “Canon, ¿estética o pedagogía)”. Ínsula 600 (1996): 3-4.

PRIETO De PAUla, Ángel Luis (1996). Musa 68. Claves de la generación poética. Madrid: Hiperión.

PRIETO DE PAula, Ángel Luis. "Sobre la poesía y el estatuto de la poesía en el año 2000”. Diablotexto: Revista de crítica literaria 6 (2002): 373-390.

Prieto De Paula, Ángel Luis. "Poetas del 68... después del 75”. Anales de Literatura Española, 17 (2004): 159-183.

QuesadA, Antonio J. “Algunas ideas sobre Chatterton de Elena Medel”. Sur: Revista de literatura 7 (2015): 1-3.

RAMOs TORRES, Ramón. "Atemporalización y presentificación del mundo social en la sociología contemporánea”. Política y sociedad 1 (2014): 147-176.

Ricoeur, Paul (2009): Ideología y utopía. Barcelona: Gedisa.

RiERA, Carmen (1988). La escuela de Barcelona. Barcelona: Anagrama.

RóDENAS, Domingo (2003). La crítica literaria en la prensa. Madrid: Marenostrum.

RoDríGueZ,, Claudio (2985). Conjuros. Barcelona: José Batlló.

RODRíGUEZ, Juan Carlos (1974). Teoría e historia de la producción ideológica. Madrid: Akal.

RodRíGUEZ, Juan Carlos (1994). La norma literaria. Granada: Diputación Provincial de Granada.

RODRÍGUEZ, Juan Carlos (1999). Dichos y escritos (Sobre "La otra sentimentalidad" y otros textos fechados de poética). Madrid: Hiperión.

RoDRíGUEZ, Juan Carlos (2016). "La poesía y la sílaba del no (notas para una aproximación a La Otra Sentimentalidad y a la poética de la experiencia”. SÁNCHEZ, Remedios (coord.). Palabra heredada en el tiempo. Tendencias y estéticas en la poesía española contemporánea (1980-2015). Madrid: Akal: 9-25.

Ruiz Casanova, José Francisco (2007). Anthologos: Poética de la antología poética. Madrid: Cátedra.

SALAS DíAZ, Miguel. "Medel, Elena, Tara, DVD Ediciones, Barcelona, 2006, 80 pp.”. Ogigia. Revista electrónica de estudios hispánicos 1 (2007): 93-94.

SÁNCHEZ GARCÍA, Remedios. "Poesía ante la incertidumbre". Cuadernos hispanoamericanos 643 (2012): 109-119. 
SÁnchez García, Remedios y Bianchi, Marina (eds.) (2014). Humanismo solidario. Poesía y compromiso en la sociedad contemporánea. Madrid: Visor.

SÁNCHEZ GARCíA, Remedios y GEIST, Anthony L. (eds.) (2015). El canon abierto: última poesía en español (1970-1985). Madrid: Visor.

SÁNCHEZ GARCía, Remedios (coord.) (2016). Palabra heredada en el tiempo. Tendencias y estéticas en la poesía española contemporánea (1980-2015). Madrid: Akal.

SÁNCHEZ ROBAYNA, Andrés (2005). "Una versión de la poesía hispánica contemporánea". SÁNCHEZ RobAYNA, Andrés y DoCE, Jordi (eds.). Poesia bispánica contemporánea. Ensayos y poemas. Barcelona: Galaxia Gutemberg: 13-42.

SARria Cuevas, José (2016). "Literatura hispanomagrebí: compromiso literario y su relación con el Humanismo Solidario". SÁnCHEZ, Remedios (coord.). Palabra heredada en el tiempo. Tendencias y estéticas en la poesía española contemporánea (1980-2015). Madrid: Akal: 415-426.

SLOTERDijK, Peter (2007). En el mundo interior del capital. Para una teoría filosófica de la globalización. Madrid: Siruela.

TALENS, Jenaro (1989). De la publicidad como fuente historiográfica: La generación poética española de 1970. Valencia: Universitat de València, Centro de Semiótica y Teoría del Espectáculo.

TALENS, Jenaro (2005). "Contrapolíticas del realismo (de ética, estética y poética)". SÁNCHEZ ROBAYNA, Andrés y DOCE, Jordi (eds.). Poesía hispánica contemporánea. Barcelona: Galaxia Gutemberg: 129-159.

TORÉS, Albert (2016). "Los puentes del Romanticismo cívico y el Humanismo Solidario". Sánchez, Remedios (coord.). Palabra heredada en el tiempo. Tendencias y estéticas en la poesía española contemporánea (1980-2015). Madrid: Akal: 393-402.

TORRE, Guillermo de la (1943). La aventura y el orden. Buenos Aires: Losada.

VALVERDE, Fernando (2016). "Poesía ante la incertidumbre, una responsabilidad compartida". Sánchez, Remedios (coord.). Palabra heredada en el tiempo. Tendencias y estéticas en la poesía española contemporánea (1980-2015). Madrid: Akal: 305-314.

VÁzQuez Montalbán, Manuel (1998). La literatura en la construcción de la ciudad democrática. Barcelona: Mondadori.

VILARÓs, Teresa (1998). El mono del desencanto (Una crítica cultural de la Transición española). Madrid: Siglo XXI.

VillenA, Luis Antonio de (ed.) (1986). Postnovísimos. Madrid: Visor.

VillenA, Luis Aantonio de (ed.) (1992). Fin de siglo. El sesgo clásico en la última poesía española. Madrid: Visor.

VillenA, Luis Antonio de (ed.) (1997). 10 menos 30. La ruptura interior en la poesía de la experiencia. Valencia: Pre-Textos.

VillenA, Luis Antonio de (ed.) (2003). La lógica de Orfeo (antología). Madrid: Visor.

VILLENA, Luis Antonio de (ed.) (2010). La inteligencia y el hacha (Un panorama de la Generación poética de 2000). Madrid: Visor.

VillenA, Luis Antonio de (2016). "Postnovísimos, experiencia, realismo meditativo". SÁnCHEZ, Remedios (coord.). Palabra heredada en el tiempo. Tendencias y estéticas en la poesía española contemporánea (1980-2015). Madrid: Akal: 43-48.

ViriLIO, Paul (1999). El arte del motor. Aceleración y realidad virtual. Buenos Aires: Editorial Manantial. 
VIVES PÉREZ, Vicente. "La generación del 68 y la irrupción de la poética posmoderna”. Dicenda. Cuadernos de Filología Hispánica 31 (2013): 251-269.

VVAA (1987). 1917 versos. Madrid: Ediciones Vanguardia Obrera.

VVAA (2003). 25 poetas jóvenes españoles. Madrid: Hiperión.

VVAA (2011). Poesía ante la incertidumbre. Antología (Nuevos poetas en español). Madrid: Visor.

VVAA (2017). Voz vértebra. Antología de poesía futura. Madrid: Kriller 71. 